\title{
Coral Reef Biodiversity in the Face of Climatic Changes
}

\author{
Stéphane La Barre \\ Université Pierre et Marie Curie-Paris 6, UMR 7139 Végétaux marins et Biomolécules, \\ Station Biologique F-29682, Roscoff \\ CNRS, UMR 7139 Végétaux marins et Biomolécules, Station Biologique F-29682, Roscoff
}

France

\section{Introduction}

Loss of marine biodiversity seems inevitable in the $21^{\text {st }}$ century. In benthic marine systems, survivors will have to acclimatize to seawater constantly increasing in temperature and evolving chemically, while also needing to out-compete new opportunistic neighbors and possibly facing increased predation pressure. Last but not the least, with a metabolism already pushed to its limits, survivors will have to fight against emerging diseases.

Recent studies have shown that thermal stresses on coral reef scleractinians (Vega Thurber et al., 2009), sponges (Webster et al., 2008) and coralline algae (Webster et al., 2010a) induce changes from a balanced, functional associated microflora to a pathogen-dominated one, causing disease before the physiological tolerance limits of the hosts are reached. Changes in water chemistry (loss of bioavailable calcium carbonate due to acidification) and other stress factors (temperature, salinity, oxygen, sedimentation, etc., due to the greenhouse effect or to its climatic consequences) will affect biodiversity and community structure, and in the long term induce disaggregation of limestone scaffolds.

The first section of this chapter is devoted to a presentation of the mechanisms involved in the climate-driven loss of coral reef biodiversity predicted within the next few decades in response to increasing anthropogenic pressure. Most of the arguments developed in the following sections reflect recent work published on reef-building corals, sponges and algae and their associated macro- and micro- biota, as major reef "engineers" (Wild et al., 2011). Biodiversity and chemodiversity have always been linked in the history of our planet. Both have undergone explosively creative periods, and at other times suffered dramatic losses or even extinctions followed by the emergence of better-adapted forms of life. Coral reefs have existed for many millions of years and are no exception to this. The final part of this chapter is a reflection on how a few generations of humans have been able to overexploit the planet's biodiversity for their own immediate benefit, and harm it by producing and disseminating freak molecules and genomes for which the ocean is the final depository. The threat to coral reefs comes more from effluents of highly industrialized nations than from the daily activities of low-revenue populations living on site (Donner \& Potere, 2007). We now need to apply our creativity or "intello-diversity" to preserving existing natural equilibriums to make the planet safe for future generations. 


\section{Global chemistry and coral reef biostructures}

\subsection{Healthy coral reefs are efficient ecosystems}

Coral reefs are marine structures made of biogenic calcium carbonate mineralized from dissolved bicarbonate and calcium ions. Scleractinian corals are the largest contributors to the formation of huge and solid limestone scaffolds that are home to countless communities of marine benthos and fish. Often equated to primary tropical rainforests in terms of overall biodiversity, coral reefs concentrate an estimated quarter of all identified marine species in only about $0.1 \%$ of the total oceanic surface. Restricted to pan-tropical and subtropical zones where shallow waters are warm enough throughout the year to allow photosynthesisassisted biomineralization to occur, reef-forming scleractinian corals thrive in clear nutrientlimited waters. Optimal efficiency in nutrient cycling is achieved when overall equilibrium between all trophic levels, i.e. from higher predators to microbes, is reached. The higher the biodiversity, the more efficient the carbon and nitrogen fluxes, and the lower the probability of epidemics of bacterial pathogens or of predators upsetting the equilibrium between compartments. Azam \& Malfatti (2007) stress on the importance of studying the nano and micro scale microbial structuring of marine ecosystems in order to better understand food webs and biogeoclimatic cycling. Coral reefs are of various types in relation to their location relative to land (fringing reefs, lagoon reefs, barrier reefs) or to geology (remote atoll reefs). Coral reef biodiversity hotspots occur where optimal equilibrium benefits from landassociated ecosystems and the fluxes they generate. More generally, the association of coral reefs with coastal ecosystems is both beneficial and also a source of problems when the above equilibrium is broken (Dinsdale et al., 2008). Like forests, reefs represent a substantial source of revenue to humans in goods and services (Moberg \& Folke, 1999), estimated at a global 29.8 billion dollars per year in 2003 (Cesar et al., 2003), but this revenue is already being heavily compromised due to overexploitation (Cesar, 2002; Lough, 2008). The preservation of coral reef biodiversity is becoming a central ecological concern, and an economic issue to hundreds of millions of islanders and coast-dwellers living off the associated resources.

\subsection{Climate change and human interference affect natural equilibria}

Production of carbon dioxide and other greenhouse effect promoters, like methane and nitrogen oxide, together with water vapor, contribute to shielding nocturnal infra-red reemissions that are necessary for the cooling of surface seawater and land. This phenomenon, known as the greenhouse effect or global warming, is generated by natural phenomena and by human activities. Natural production of greenhouse gases (by volcanism in particular) can usually be buffered by carbon and nitrogen fixing organisms, mainly bacteria, phytoplankton and forest trees, albeit at the expense of temporary and localized loss of biodiversity, as witnessed by coral skeleton biomarkers. Atmospheric enrichment of greenhouse gases by agricultural and industrial practices is accelerating at an alarming rate and its effects are now perceivable and measurable, but there is currently no means of accurately predicting how much reef biodiversity will be lost in 20, 50 or 100 years from now. In all of the proposed scenarios, estimates of recovery of existing taxa vs. replacement by more resistant or more adaptable taxa are highly speculative.

\subsubsection{Greenhouse effects on coral reef biota}

The shielding effect of greenhouse gases leads to three categories of damage to coral reefs: 
- overheating of air and seawater that causes bleaching of corals, sponges and photosymbiotic invertebrates, and mortality in case of lasting episodes. In addition, destruction of the high altitude ozone layer by fluorinated volatiles is likely to reduce the shielding of harmful short-wave radiations that are genotoxic to exposed biota,

- gradual acidification of seawater causes gradual decalcification in biomineralizers, like scleractinian corals, coralline algae, foraminiferans, and calcifying sponges,

- increased evaporation and condensation of water are already causing more severe and more frequent hurricanes that may destroy entire portions of reefs, both mechanically by wave action and by osmotic damage to polyps by abundant rainfall,

- The combination of low tides, warmer waters and increased UV irradiance is likely to increase the strength and the persistence of the bleaching phenomenon, hence diminishing the chances of recovery of coral colonies.

\subsubsection{Man has colonized most reef environments, denaturing them in the process}

Human influence on coral reefs is enormous, multifaceted and expanding at a fast rate. Apart from the generation of gases producing the greenhouse effect, "contact" influences result from (i) natural landscape remodeling, (ii) industrial dumping, and (iii) household pollution. All have direct and readily observable effects on marine biota, with alien molecules killing sensitive species and microbial pathogens plaguing entire populations to extinction.

\subsection{Bleaching of shallow water photosymbiotic systems}

Bleaching has been defined as the loss of integrity of the photosymbiont - host relationship (hermatypic corals and some sponges) or the loss of photosynthetic pigments by the photosymbiont (zooxanthellae). Following the first large-scale bleaching events, Brown (1997) classified the causes of bleaching in corals as (i) elevated/decreased seawater temperature, (ii) solar irradiation, (iii) reduced salinity, and (iv) microbial infection. Longterm bleaching leading to mortality of entire expanses of shallow-water reefs was clearly identified as pathological in contrast to short-term episodes of occasional bleaching that allow corals to renew their resident zooxanthellae with better adapted clades (Suggett \& Smith, 2011), some of which, e.g. Symbiodinium clade D may be regarded as indicators of habitat degradation more than agents of adaptation to warming (Stat \& Gates, 2011). Research over the last decade has benefited from two major analytical developments: (i) functional genomics and transcriptomics that allow exploration of stress responses at cellular and whole-organism levels (Reitzel et al., 2008), and (ii) microbial metagenomics that allow culture-independent comparative analyses of bacterial and viral (Vega Thurber et al., 2008) profiles of impacted vs. healthy organisms (Vega Thurber et al., 2009), based on robust database on the former (e.g. Wegley et al., 2007). Various scenarios have been proposed to account for coral bleaching, leading to debate as to the respective importance of causative factors of mortality of corals (Bourne et al., 2009; Leggatt et al., 2007; Rosenberg et al., 2007; Rosenberg et al. 2007b), while the functional importance of bacteria in essential coral life processes is emerging from multiple examples (Mouchka et al., 2010) that also reveal their evolutionary significance (Fraune et al., 2010).

\subsection{Decalcification of reef-structuring biomineralizers}

Decalcification is the decrease or loss of the ability of marine invertebrates and of calcifying algae and plankton to perform accretion of calcium into adapted and functional skeletal 
structures, due to increasing seawater protonation. Biomineralization is a finely-tuned process requiring proper equilibrium between external (seawater) and internal (body fluid) chemistries. Individual susceptibilities to seawater acidification vary between organisms.

\subsubsection{Coral reefs as contributors or sinks to atmospheric $\mathrm{CO}_{2}$}

There has been controversy as to whether the global impact on atmospheric $\mathrm{CO}_{2}$ by coral reefs is positive or negative. Coral respiration produces carbon dioxide and so does calcification on a mole-to-mole basis (Gattuso et al., 1995), a fact that tends to place corals as net contributors to atmospheric carbon dioxide. On the other hand, communities dominated by coralline algae in temperate seas may act as carbon sinks (Bensoussan \& Gattuso, 2007), an important consideration in estimating carbon dioxide fluxes in reef systems with high algal biomass. Furthermore, factors such as the influence of land runoff on inshore reefs may explain that in some areas, coral communities act as carbon dioxide sinks rather than sources (Chisholm \& Barnes, 1998). The debate on carbon cycling in coastal marine environments is now taking a new dimension with consideration of functional interactions of marine microorganisms with their hosts. Useful information about calcification and ocean acidification is found in pages of the website of the European EPOCA project (http://epoca-project.eu/) and of the Woods Hole Oceanographic Institute website (http:/ / www.whoi.edu /OCB-OA/FAQs/).

\subsubsection{Key parameters in marine biomineralization}

Biomineralization is widespread in marine eukaryotes and in all marine ecosystems. Carbonates, phosphates, oxides, silicates, etc. are produced by marine organisms to form tissue supporting, defensive or protective structures such as shells, spicules, skeletons, tests, or teeth in invertebrates (e.g. Bentov et al., 2009). Calcification in the form of carbonates is the most widespread form of biomineralization, and calcite (coralline red algae and foraminifers) and aragonite (corals and green calcifying algae) represent the most important contributors to the hard substrata and lagoon sand of coral reefs. Biomineralization results from a finely controlled interfacial chemistry between the organisms and seawater. Basically, the carbonate system in seawater is defined by four master variables, total or dissolved inorganic carbon (DIC), total alkalinity (TA), the partial pressure of $\mathrm{CO}_{2}$ in water $\left(\mathrm{pCO}_{2} \mathrm{w}\right)$, and $\mathrm{pH}$ (Blackford, 2010). Knowledge of any two of these along with basic physical properties is sufficient to derive the other two and the carbonate saturation state omega $(\Omega)$, bicarbonate ion concentration $\left(\left[\mathrm{HCO}_{3}^{-}\right]\right)$and carbonate ion concentration $\left(\left[\mathrm{CO}_{3}{ }^{2-}\right]\right)$. Marine calcifiers do not all respond in the same way to $\Omega$ thresholds, and acidification will most strongly affect species and their larvae that are the most susceptible to lowering carbonate saturation state.

\subsubsection{Biomineralization and short and long term consequences on coral reefs}

Biomineralization of $\mathrm{CaCO}_{3}$ (calcification) in the oceans, undertaken by planktonic eukaryotes in the photic zone of open oceans and numerous plants, invertebrates and protists in coastal zones, is one of the major processes that control the global carbon cycle.

The atmospheric partial pressure of carbon dioxide $\left(\mathrm{pCO}_{2}\right)$ will almost certainly be double that of pre-industrial levels by the year 2100 and will be considerably higher than at any time during the past few million years. The oceans are a principal sink for anthropogenic $\mathrm{CO}_{2}$ with an estimated $30 \%$ increase in surface water protonation since the early 1900s and with a projected drop in seawater $\mathrm{pH}$ of up to 0.5 units by 2100 (Hall-Spencer et al., 2008), i.e. down to 7.6 to 7.8 in 100 years time (Clark et al., 2009). 
Open ocean life forms such as nanoplankton represent a considerable biomass of calcifying organisms with very short generation times, and are thus particularly susceptible to acidification and are potential bio-indicators of the progress of decalcification. Coccolith fossil records indicate that responses to past volcanism-related seawater acidification included malformations and dwarfism, and that carbonate recovery is a very long process (Erba et al., 2010).

Bioavailability of calcium and bicarbonate ions in seawater is therefore central to the question of calcification by corals, coralline algae and other biomineralizers, and to the success of their larvae or spores in metamorphosing into viable adults. A progressive lowering of the $\mathrm{pH}$ of seawater (acidification) occurring as a result of greenhouse effects would tend to keep divalent cations, e.g. calcium and magnesium, in soluble form in sea water, thus requiring an ever increasing metabolic effort on behalf of the organisms or of their larvae or spores to achieve an acceptable level of calcification for their needs.

Pluteus larvae of sea-urchins from various latitudes subjected to different $\mathrm{pH}$ levels (6.0 to ambient) suffer from reduced size and survival time, some also showing degradation of fine skeletal structures (Clark et al., 2009). Knowing the importance of urchins (e.g. Diadema) in regulating algal proliferation on coral reefs, imbalances between trophic fluxes are to be expected if key grazers are eradicated. An interesting question is that of the effects acidification will have on settling larvae of calcifying benthic organisms that often rely on a combination or a sequence of physical, chemical and contact cues to initiate their establishment and induce cementation. Barnacle larval proteome responds to ambient acidification by producing unique protein signatures, an expression considered of adaptive value by Wong et al (2011, in press). Little is known about the conditions in which calcification inducing genes are activated in settling coral planulae. The physiological mechanisms of the responses of adult coral colonies to the direct effects of $\mathrm{CO}_{2}$ or to changes in $\mathrm{HCO}_{3}$ - concentration have been investigated (Marubini et al., 2008), the net effect being a decrease in the calcification of coral skeletons. The development and survival of mollusks has been considerably affected since preindustrial $\mathrm{CO}_{2}$ concentrations of $250 \mathrm{ppm}$, and the survival of commercially important species will be compromised in year 2100 with $\mathrm{CO}_{2}$ levels expected to reach 750 ppm (Talmage \& Glober, 2010).

Loss of benthic diversity will occur as soon as biomineralizing organisms (essentially corals and coralline algae, foraminiferans and other benthos to a lesser extent) will no longer be able to adequately turn dissolved cations into insoluble cement, meaning their larvae may no longer be able to settle, metamorphose and build a strong mineral matrix upon a steadily cemented holdfast. Solid substratum being one of most important resources in shallow marine habitats (Jackson \& Buss, 1975; Connell, 1978), biodiversity on coral reefs will inevitably be affected by the non-replacement of disaggregating limestone structures, dwarfism or crooked shells. Gradual seawater acidification may lead to a new mass extinction of marine species, this time as a result of human interference rather than of cataclysmic events at planetary scale (Veron, 2008). There is an urgent need for studying the effects of climatic changes on sensitive species that may act as bioindicators (Sammarco \& Strychar, 2009), and to have coordinated environmental policy-making and management (Sammarco et al., 2007).

\subsection{Human exploitation of coral reefs}

When the soil-fixing coastal vegetation is destroyed, the physico-chemistry of lagoon waters is upset with negative impacts on all stages of the adult and plankton instars of marine 
biota. When mangroves are removed, the nutrient cycling efficiency needed to maintain biodiversity along a seaward gradient is overproductive for heterotrophic microorganisms and underproductive for eukaryotic consumers. Biodiversity loss in coastal waters is the result of ever-increasing activity of sea farming, fishing and tourism in tropical countries. Poor household waste management and the use of fertilizers cause oxygen depletion of seawater with suffocation of reef invertebrates and fish. In the longer term, nutrient enrichment, by favoring algal growth, will cause a strong imbalance between trophic compartments of coral reefs, to the detriment of coral survival.

\section{Macrophytic algae}

\subsection{Macrophytic algae are well-adapted to coral reefs}

Macrophytic algae are major benthic contributors to the living intertidal and subtidal biomasses of most temperate and subpolar coastal regions. In contrast to kelp forests dominating nutrient-rich colder waters, the presence of macrophytic algae appears secondary to that of invertebrates in coral reefs that naturally develop in oligotrophic conditions. However the three macroalgal lineages (red, brown and green) have many representatives that are well adapted to the numerous communities found in all reef types and zones, as witnessed by their extremely varied growth forms. In addition, the rhodophyte (red) and the chlorophyte (green) algae have calcifying forms that actively contribute to substrate-forming calcification (by calcareous green algae) and to the cementation of loose aggregates (by encrusting coralline red algae). If stony corals are usually regarded as the framework architects, algae certainly play a role in the building and consolidation of reef assemblages, along with other biomineralizers such as sponges, tube worms and foraminifera.

\subsubsection{Calcareous chlorophytes and coralline rhodophytes are essential components of reef ecosystems}

Calcification, mostly in the form of calcium carbonate, has arisen independently in the three algal lineages (though to a much lesser extent in the brown algae), reflecting different growth strategies to those of non-calcifying forms. On coral reefs, heavily calcifying algae can adopt two forms: (i) geniculate, i.e. made up of calcified segments separated by flexible joints called genicula, and (ii) crustose, i.e. encrusting forms that lack genicula and grow as thin encrusting patches on hard substratum. The articulated chlorophyte Halimeda provides a major calcium carbonate contribution to the substratum of reef flats, i.e. the sand, and to sea grass beds which host many juvenile forms of fish and invertebrates. Crustose coralline red algae are arguably the most abundant organism (plant or animal) to occupy hard substrata within the world's marine photic zone. Unattached ball-like rhodoliths and maerl are responsible for reef formations called algal ridges in tropical wave-exposed environments (Steneck \& Martone, 2007), while encrusting forms are responsible for the cementation of rubble and mineral debris into larger structures onto which other benthos can attach. Coralline algae provide food to sea urchins, parrot fish, limpets and chitons, and together with scleractinian corals and sponges they provide the framework for the development of complex communities of invertebrates. Furthermore, crustose coralline algae (CCA) are known to play a crucial role in the settlement and metamorphosis of larvae of sea urchins (Huggett et al., 2006), starfish (Johnson \& Sutton, 1994), mollusks (Williams et al., 2008), corals (Negri et al., 2001; Webster et al., 2004), and possibly 
sponges (Carballo \& Avilla, 2004). Several CCA metabolites have been identified as potential inducers, e.g. 11-deoxyfistularin-3, a bromotyrosine derivative which stimulates settlement of coral planulae in the presence of algal carotenoids (Kitamura et al., 2007), $\delta$ aminovaleric acid and other salts which induce competent abalone larvae (Stewart et al., 2008), and dibromomethane which induces sea-urchins and the invasive slipper limpet Crepidula fornicata (Taris et al., 2010). Bacterial consortia which form specific biofilm-like CCA-associated assemblages, and/or their products have also been shown to act as inducers (Johnson et al., 1991) in the settlement and metamorphosis of larvae (reviewed by Hadfield, 2011). Coralline algae do not grow in sediment-rich coastal waters. Organisms with larvae that specialize in settling on CCA are naturally excluded from zones that are unsuitable for the growth of their host (Fabricius \& De'ath 2001). This is a possible explanation for the lower species abundance and community composition of CCAs in coastal environments receiving sediments from rivers or from heavy rainfall washing unstabilized top soil (e.g. mining sites), in addition to insufficient bioavailability of calcium for calcification. Increasing metabolic cost associated with global climate change may offset the advantages of calcification, and recent increases in disease may indicate that oceans are becoming a more stressful environment for calcified algae. Dessication, temperature and light are capable of inducing 50\% pigment loss within 24 minutes of emersion in the model species Calliarthron tuberculosum, and predictionoriented models based on the combined effects of these parameters are being developed to evaluate the effects of progressive climatic changes (Martone et al., 2010). Taking Neogoniolithon fosliei (a primary reef-builder) as a case study, Webster et al. (2010a) demonstrated a strong correlation between elevated sea water temperature $\left(32^{\circ} \mathrm{C}\right)$ and (i) de-pigmentation, (ii) a large shift in the structure of microbial communities associated with CCAs, (iii) development of chlorophytic endophytes, and (iv) a dramatic decrease in the ability to induce metamorphosis of coral planulae, i.e. loss of bacterial surface flora. Physiological experiments have recently shown that temperature stress induced bleaching of the coralline alga Corallina officinalis was the result of pigment loss following an oxidative burst, i.e. an increase in production of $\mathrm{H}_{2} \mathrm{O}_{2}$ and other reactive oxygen species and decrease in quenching capacity of the haloperoxidase system (Latham, 2008).

\subsection{The phycosphere and its associated microbiome 3.2.1 Algae are phylogenetically ancient and have coevolved in association with
microbes}

Macrophytic algae belong to three distinct lineages that diverged early in the history of eukaryotic evolution. Red and green algae (including plants) arose from a common ancestor (Keeling, 2010) through primary endosymbiosis, i.e. engulfing of a cyanobacterium by an aerobic eukaryote, the former becoming the original plastid. Fossils as old as 1 to 1.2 billion years (mid-Proterozoic) indicate the existence of filamentous forms of both red and green algae at the root of present day plants (Javaux et al., 2004). Brown algae (stramenopiles) evolved much later as a consequence of secondary endosymbiosis (engulfing of a unicellular red alga by an aerobic eukaryote). Analysis of the genome of the filamentous brown alga Ectocarpus siliculosus (Cock et al, 2010) has provided evidence of the independent evolution of multicellularity within the stramenopile lineage which also includes diatoms. All three lineages have since developed into thousands of different forms with sizes ranging from microscopic (e.g. endophytes) to gigantic (e.g. brown kelp Macrocystis) and adaptation to most known aquatic ecosystems. Their capacity to survive eons of biotic and abiotic stresses 
and their adaptability to colonize extreme environments has emerged through finely tuned interactions and co-evolution with microbial organisms (La Barre \& Haras, 2007).

\subsubsection{Macrophytic algae control surface microbial colonization and biofilm formation}

A recent paper by Goecke et al. (2010) reviews the various ways in which extant marine macroalgae and bacteria interact positively and negatively via chemical mediators. Adult macroalgae are strongly susceptible to surface colonization, as they provide potential surfaces for settlement of epibionts. As well as increasing the weight of the thallus and making it mechanically fragile, epibiosis significantly reduces the surface area available for photosynthesis. On inert substrata, macrofouling is generally facilitated by the presence of bacterial biofilms, as demonstrated by numerous studies (Fusetani, 2011). Marine algae produce photosynthates that serve as prime carbon sources for bacteria, as witnessed by the surprisingly large microbial biodiversity found on their apparently "clean" surfaces, but the surfactant nature of these carbohydrates strongly discourages adhesion. Biofilm formation is also discouraged by molecules that (1) interfere with bacterial quorum-sensing activation, e.g. hypobromous acid in the brown kelp Laminaria digitata (Borchardt et al., 2001) or halogenated furanones produced by the rhodophyte Delisea pulchra, and (2) act as decoy analogs of bacterial acyl-homoserine lactones which induce quorum sensing (Manefield et al., 2002). Surface compounds produced by the phaeophyte Fucus vesiculosus are capable of modulating both epibiotic development and bacterial biofilm production (Lachnit et al., 2010). Flow-cell experiments (this author, unpubl. results) have shown that the thickness and 3-D architecture of monospecific biofilms of model bacteria isolated from inert substrata and from Laminaria digitata blades are differentially affected by exposure to exudates and surface compounds extracted from this kelp. Antifouling programs are now integrating biofilm denaturation studies into their strategies, an ecologically sound alternative to the use of toxic ingredients.

\subsubsection{Microbial pathogenic infection results in coordinated immune responses from infected algae}

Bacteria interact with algae mostly in a non-invasive manner until older tissues can no longer resist saprophytic degradation by bacteria or bacterial consortia that have the appropriate lytic enzymes. However, fortuitous bacterial intrusion following mechanical damage or exposure to specific signal substances (elicitors) may trigger an oxidative burst followed by intracellular responses comparable to classical inflammation, as part of an innate immune mechanism (Weinberger, 2007). In brown algae, microbial infection is strongly inhibited by the emission of halogenated compounds that may have bactericidal or bacteriostatic activities in the immediate hydrosphere of the thallus, due to an efficient apoplastic enzymatic machinery (Butler \& Carter-Franklin, 2004) that can be activated in a non-systemic fashion. Indeed, red and brown algae are reported to use both animal-like (eicosanoid) and higher plant-like (octadecanoid) oxylipins in the regulation of defense metabolism for protection against pathogens and grazers or in response to elicitors of defense responses (Cosse et al., 2009). Tetracyclic brominated diterpenes active against multi-resistant strains of the nosocomial bacteria Staphylococcus aureus have recently been isolated from the red alga Sphaeorococcus (Smyrniotopoulos et al 2010), suggesting efficient antibiotic responses against potentially infective strains. Kornprobst (2010a) provides a comprehensive review of bioactive metabolites of various chemical classes from red, brown 
and green algae. Compounds with have antibacterial activities are now inspiring ecological alternatives to classical antifouling paints and coatings based on genotoxic heavy metal formulations.

Certain parasitic endophytes (fungi and minute filamentous algae) are capable of penetrating the outer cuticle of red and brown algae and causing modifications of the growth of the host (e.g. Gauna et al., 2009). Some bacteria have the enzymatic machinery capable of breaking down cell wall polymers into absorbable energy sources, as well as being resistant to the defense compounds elicited following their intrusion. Their biotechnological potential for the production of low MW bioactive components from bulk tissue is being investigated (e.g. Kim et al., 2009; Colin et al., 2006). Bacterial epidemics are occasionally reported, leading to the complete destruction of local natural populations (e.g. Laminaria hyperborea in western Brittany), or of seaweed farms of brown (e.g. Laminaria japonica, Wang et al., 2008), or of tropical red algae (e.g. carrageenophytes, Largo et al., 1999).

\subsubsection{Bacteria are also essential to the development, fitness and defense of algae}

The life cycle of Ulvales (Chlorophyta) is clearly dependent upon the presence or the association of adequate bacterial strains. Production by a bacterium of thallusin, a Ncontaining carboxylated diterpene, induces the morphogenesis of foliose thalli of the green ulvophyte Monostroma oxyspermum from filamentous cell aggregates (Nishizawa et al., 2007), and more generally from Enteromorpha-like filamentous forms into Ulva-like foliose forms (Matsuo et al., 2005). Swimming Ulva tetrazoospores are strongly influenced by specific quorum-sensing signals liberated from bacterial biofilms (review by Joint et al., 2007) resulting in settlement and metamorphosis in their vicinity. Ulva australis favors colonization of its surfaces by Roseobacter gallaeciensis and by Pseudoalteromonas tunicata which coexist as segregated microcolonies, and modulate the settlement of other competing strains essentially by (i) production of the antibacterial protein AIpP by P. tunicata and (ii) biofilm invasion and dispersion by R. gallaeciensis (Rao et al., 2006). Molecular investigations on Ulva australis showed that alphaproteobacteria (dominated by the Roseobacter clade) and Bacteroidetes are a regular and stable component of this alga's functional microbiome (Tujula et al., 2010). The Roseobacter clade is now regarded as an essential functional component of the microbiome of phytoplankton (both intra- and extracellularly), assisting in both primary and secondary roles (Geng \& Belas, 2010), as well as seemingly in a number of macrophyte associations of symbiotic nature. Brown algae shelter bacterial communities that may vary according to their location on the thallus, partly due to differences in surface chemistries (q.v. review by Goecke et al., 2010), and to the mode of colonization, i.e. by planktonic bacteria on distal surfaces and by surface contamination of the holdfast by epibionts and complex microbial biofilms. Among the numerous and unidentified non-cultivatable strains, it can be assumed that some of have neutral or beneficial interactions with their host.

\subsection{Algae and their chemical language}

\subsubsection{Thalli control their immediate hydrosphere... and the atmosphere}

Lam \& Harder (2007) have described how macroalgae can selectively control their immediate surroundings by diffusing waterborne chemicals that prevent settlement by potentially fouling microbiota and epibiota. The emission of cocktails of volatile halogenated C1-C3 compounds has been extensively reported in red (e.g. Kladi et al., 2004) and in brown (e.g. La Barre et al., 2010) algae, with impacts beyond the proximal underwater effects on atmospheric chemistry. Green algae are responsible for massive 
releases of dimethylsulfoproprionate (DMSP) and diffusion of their breakdown products (acrylate and dimethylsulfide) into the atmosphere, which may create conditions favorable for the dispersal of their gametes (Welsh et al., 1999). This is reminiscent of cloud-forming emissions of iodinated compounds above kelp beds (Ball et al., 2010). Thus benthic algae and phytoplankton actively participate in the cycling of iodine, bromine, chlorine and sulfur at the water-air interface, while responding to requirements at both cellular and population levels. Biomass breakdown following massive blooms of DMSP algae and Prymnesophytes may cause severe anoxia and hydrogen sulphide intoxications to local fauna and seashell farming, pointing out the necessity for proper control of nutrient enrichment of coastal waters.

\subsubsection{Algal metabolites alter the fitness and growth of their benthic neighbors}

In addition to volatile compounds, macroalgae owe their competitiveness to the production of whole arrays of metabolites that are bioactive (i) by contact interactions with adjacent alien tissues, using lipid-soluble compounds (Rasher \& Hay, 2010a), (ii) by diffusing waterborne chemicals, or (iii) by altering the functional microbial flora of their invertebrate neighbors thereby encouraging the development of pathogenic strains. Damage to the scleractinian cover on the outer reef slopes in various localities of the Central and South Western Pacific by blooms of Asparagopsis taxiformis may be the result of one or more of these modes of action. Toxic volatile or diffusible halogenated compounds, like haloforms, methanes, ketones, acetates and acrylates, were described for A. taxiformis and its sibling species A. armata (Mc Connell \& Fenical, 1977; Woolard et al., 1979; Kladi et al., 2004). Thick mats can overrun live scleractinian colonies and diffuse a range of volatile halocarbons that are considered toxic in addition to having various antimicrobial activities (Genovese et al., 2009). Hypoxia and tissue disruption of polyps at coral-algal tuft and coral-macroalgae interfaces led Barott et al. (2009) to the conclusion that erect (i.e. non crustose) algae were a constant cause of stress to adjacent coral colonies in contact or close vicinity in pairwise experimental associations.

\subsection{Algae as a crucial ecological link between corals and microbes 3.4.1 Control of biomass of algae by grazers is essential to coral reef diversity}

Algae are regarded as superior space competitors on hard substrata. However, predation is an important pressure on non-calcifying algae (Hay, 1997). The epilithic algal community is grazed by herbivorous fish, echinoderms (sea urchins), mollusks, crustaceans and worms, themselves serving as food to carnivores in a bottom-up succession of predators. Thus, small turf-like species, sporelings of macrophytes, and the unicellular forms that are associated with surface slime on sand and rubble, e.g. protein-generating cyanobacteria, represent an essential primary trophic component of the reef, generating more than half of the edible biomass of the whole food chain (Hay, 1997). A number of larger algae produce chemicals (terpenes, polyphenols and halogenated compounds) that have an inhibitory effect on grazers (see recent review by Paul et al., 2011). Fish being the largest consumers of algae and being selective in their food source, the biodiversity of seaweeds on the reef is a reflection of both the diversity of grazing modes (Burkepile \& Hay, 2010) and of the chemodiversity of the defence compounds they produce. To complete the picture, aggressive fish such as the common Pomacentrid damselfish tend to fend intruders off their territory, including foraging herbivores, thus promoting spatial and taxonomic diversity in the distribution of reef algae (Brawley \& Adey, 1977). 


\subsubsection{Overfishing is linked to algal and microbial development and to coral decline}

The Philippines and Indonesia include the western half of the Coral Triangle of marine biodiversity, which extends eastwards to New Guinea and the Solomon islands. One quarter or more of the human populations of these islands live in coastal areas and derive their revenues from coral reef production, on a non-sustainable basis.

Overfishing, besides causing mechanical damage to coral biota (wading, use of explosives and use of dragnets) modulates the predation pressure on benthic algae in many reefs worldwide, with consequences for corals and their associated biodiversity. Near extinction of reef sharks and other carnivorous fish and of grazing herbivores has a dramatically positive incidence on algal biomass and average size in overexploited reefs worldwide (Hay, 1997 , Sotka \& Hay, 2009). The resulting increase in the production of photosynthates feeds a bacterial population that is potentially pathogenic to corals. Disrupting the coral-microbe relationship by organic carbon loading (dissolved organic carbon (DOC), i.e. mainly carbohydrates) can directly cause coral mortality by over-stimulating growth of coral mucus-associated microbes (Kuntz et al., 2005). An analysis of the gradual decline of Jamaican coral reefs by the marine microbiologist Forest Rohwer (2010) led him to define this self-feeding loop as the DDAM model (DOC>disease>algae>microbes), which can only be broken by top down herbivory that reduces the algal biomass to levels compatible with the development of a functional scleractinian microbiome. Future management policies should ensure that key algae consumers be identified and protected in reef areas susceptible to recurrent blooming of coral damaging species (Rasher \& Hay, 2010b).

\subsubsection{Farming of macroalgae in tropical regions also suffers from climatic changes}

Farming of macrophytic algae for the food and the pharmacological industries provides an alternative activity to fishing and tourism for entire communities in tropical islands (Indonesia, Philippines, Madagascar and the Caribbean islands). However, algal monoculture can be risky. The carrageenophytes Eucheuma and Kappaphycus, that have the capacity to adjust to hyper and hypo salinity changes encountered in shallow tropical waters (q.v. Teo et al., 2009), are prone to bacterial plague disease ("ice-ice"). Such epidemics have caused occasional eradication of entire populations (Largo et al., 1999), with total loss of the livelihood of farmers. Seasonal infestations by filamentous endophytes of Malaysian Kappaphycus/Eucheuma farms which are attributed to seasonal changes (Vairappan, 2006) may be an aggravate bacterial infections.

\subsection{Exotic algae may adapt to new environments as climate changes 3.5.1 Invasive species}

The large-scale introduction of non-indigenous species and homogenization of the world's biota has long been considered among the greatest threats to species diversity (Carlton \& Geller, 1993). Before global warming became the central issue in the coral reef biodiversity literature, the necessity for proper management of reef resources had already been highlighted (Maragos et al., 1996), including the issue of species of commercial interest imported into developing countries due to the low cost of local labor. Introductions may result in competition with native biota, eventually affecting human livelihood. Whether deliberately imported (introduced) or accidentally established (invasive), alien species, like endangered species, are now identified on periodically upgraded lists. For example, the International Coral Reef Initiative (ICRI) devotes a whole section of its website (http://www.icriforum.org/) to this topic. Alien seaweed, fish, mollusks and even corals 
are listed as invasive species competing with native species for resources and being potential causes of new diseases of resident scleractinian corals.

The primary cause of invasion of new territories by alien algae is not always easy to determine, and a combination of factors usually contribute to the success of their expansion in new territory. Regular de-ballasting of huge amounts of seawater by container ships is often held responsible for the spread of exotic algae and microalgae along major maritime trade routes, eventually leading to endemic settlement points in regions where acclimation is possible (Carlton, 1996). On the other hand, massive invasions along the Mediterranean shores of the toxic Australian green alga Caulerpa taxifolia (and later of Caulerpa racemosa) are examples of accidental contaminations starting with a few individuals (Klein \& Verlaque, 2008). The displacement by these two Caulerpa species of resident halophyte meadows (e.g. Posidonia) which are home to juveniles of a number of important demersal fish is considered a threat to local biodiversity. Rhodophytes (red algae) include a number of "cosmopolitan" species that have become established in tropical environments. An example is the territorial expansion of Asparagopsis taxiformis in the South Pacific that is currently considered a serious threat to corals in New Caledonia and in French Polynesia, like its sibling species A. armata in other parts of the world.

\subsubsection{Cataclysmic events may favor supremacy of algal communities}

In tropical seas, hurricanes are becoming more frequent and more severe with global warming, resulting in near-total destruction of the coral cover in the most exposed localities, with negative impacts on larval recruitment (Crabbe et al., 2008) and hence on biodiversity. Initially, only the most resilient and hardy scleractinian species are likely to reestablish and create the replacement coral cover. Also, colonies killed by sudden and massive rainfall in shallow lagoons, or broken into fragments by brutal wave action, will provide clean substrate for fast-growing opportunists, initially mostly algal species, usually via some mediation by microbial biofilms. Once established, and provided adequate nutrients are available, algae tend to replace lost coral cover. A "side effect" of cyclone damage is the temperature-associated blooming (Chateau-Degat et al., 2005) of the neurotoxic dinoflagellate Gambierdiscus toxicus growing on algal turf that colonizes newly available substrate. With the observed trend of the increase in frequency and in severity of tropical cyclones associated with global warming, important edible fish species may increasingly become unfit for human consumption in impacted areas, a tragic situation in remote islands with low revenue populations with little choice for food substitutes.

\subsection{Nutrient enrichment favors algal development to the detriment of corals}

Non-calcifying green algae and in particular the ulvaceans, a ubiquitous group of noncalcifying chlorophytic algae, represent the most visible sign of pollution due to organic enrichment. They are distributed worldwide, from cold temperate waters to warm tropical latitudes, and from fresh or brackish to saline coastal environments, as they are both opportunistic and resilient to environmental stresses. Their taxonomy may prove difficult (Loughlane et al., 2008) with occasional reassessments made necessary owing to their phenotypic flexibility (e.g. Kang \& Lee, 2002). In temperate regions, green algae tend to be seasonal, their development dependant not only on the amount of sunlight, but also on nutrient availability and on microbial consortia associated to particular developmental stages. Spectacular biomass explosions attributed to nutrient enrichment generated by agricultural and farming practices and long daylight exposure occur during spring and 
summer. Though considered efficient at absorbing excess nutrient enrichment, if not collected they can themselves become a source of chemical pollution (hydrogen sulfide in particular) through massive bacterial degradation of the decaying biomass. In tropical environments, developing economies associated with fishing and farming of marine resources generate massive effluxes of untreated urban sewerage leading to localized blooming of chlorophytic algae. In the vicinity of reefs, bacterial enrichment by resident algae may be detrimental to coral polyps by promoting the growth of pathogenic strains at the expense of the regular associated bacterial microflora (Rohwer, 2010).

\section{Sponges}

\subsection{Sponges and reef structuration}

In association with spongin (proteinaceous) fibres, marine sponges typically biomineralize non-aragonitic calcium and magnesium carbonates (subphylum Calcispongia) or silica (subphylum Silicispongia). One of the most ancient eumetazoan lineages, sponges have adopted different modes of biomineralization and reef-forming capacities through geological time, as seawater chemistry and the bioavailability of dissolved salt species has changed periodically due to tectonic events (Stanley \& Hardie, 1998). Most reef-forming sponges have disappeared since the Phanerozoic, and present-day sponges are mostly siliceous Demosponges which are ubiquitous worldwide in their distribution (see Hooper \& Van Soest, 2002).

\subsection{Why are sponges so unique?}

The position of sponges at the root of metazoan evolution is still a hotly debated topic (see eg. Maldonaldo, 2004). Choanoflagellates, with which sponge choanocytes and metazoan lineages share genomic similarities (King et al., 2008), have emerged as model organisms for studies of early metazoan evolution. For example, the choanoflagellate genome carries the markers of three types of molecules that cells use to achieve phospho-tyrosine signaling proteins, involved in important processes (cell-cell communication, immune system responses, hormonal stimulation, etc.) in metazoans. These molecules are tyrosine kinases (TyrK), protein tyrosine phosphatases (PTP) and Src Homolgy 2 (SH2) molecules that operate as a tandem system to achieve signal recognition (Manning et al., 2008). Recent studies have also demonstrated the role of associated bacteria in the colony-forming behavior of otherwise freeliving choanoflagellates (e.g. a glycosphingolipid produced by the bacterium Algoriphagus that affects the choanoflagellate Salpingoeca rosetta (Alegado et al., 2010). Other studies mention the role bacteria may have had in the transfer of genes between unicellular eukaryotes. Nedelcu et al. (2008) provide an example of bacterially mediated lateral transfer of four stress-related genes of algal origin to a choanoflagellate host, supposedly providing the recipient cell the capacity to adapt to stress under environmental changes.

Going one evolutionary step further, Srivstava et al. (2010) have shown that the genome of the demosponge Amphimedon queenslandica contains the set of genes that correlates with critical aspects of more evolved metazoans (body plan, cell cycle control and growth, development somatic and germ-cell differentiation, cell adhesion innate immunity and allorecognition). Adaptive responses to environmental changes are known to be more rapid in microbial symbionts than in sponge cells, and bacteria may act as environmental sentinels to marine holobionts as they are particularly sensitive to environmental stressors such as heavy metal pollution (Webster et al., 2001), elevated seawater temperature, sedimentation 
and disease (Webster et al., 2011), and tolerance to eutrophication (Turque et al., 2010). Garderes et al. (2011) showed that specific bacterial quorum sensing signals can be recognized by sponge cells, triggering phagocytosis, a response proposed as part of a symbiont population-regulating mechanism.

\subsection{The sponge holobiont}

\subsubsection{Sponges shelter complex consortia of microorganisms, akin to some biofilms}

Modern reef-dwelling sponges are studied as important contributors to the constructive and bioerosive dynamics of limestone scaffolds in shallow tropical waters, but the main interest in them lies in their ability to harbor highly complex communities of micro- and macroorganisms. The overall sponge-associated microbial component is extremely diverse, bacteria alone representing up to half of the sponge biomass and occurring everywhere within their host, often as consortia. Only a very small percentage of these bacteria have been cultured in isolation. The term bacteriosponge (Reiswig, 1981) reflects the uniqueness of this prokaryotic-eukaryotic functional consortium, the holobiome being the sum total of all associated microbial components.

The demosponge microbiome occasionally includes zooxanthellae (Weisz et al., 2010) that share surface cortical layers with cyanobacteria (Li, 2009), while the eubacteria and archeae typically dominate the inner regions. Cyanobacteria can be extremely abundant within their host and provide them with competitive advantages (cyanobacteriosponges Aphanocapsa raspaigellae in Tersiops hoshinota, König et al., 2006). Some unicellular strains are widely distributed across sponge hosts and reef localities, e.g. Synechococcus spongiarum which is regarded as a generalist (Erwin \& Thacker, 2008). Sponge-specific clades of filamentous cyanobacteria, on the other hand, suggest unique coevolutionary histories (Thacker \& Starnes, 2003; Hill et al., 2006) which provide greater benefit to their hosts (Thacker, 2005). Symbiotic cyanobacteria, situated both intercellularly and intracellularly, have been reported in a large variety of marine sponges (Thajuddin et al., 2005; Usher, 2008).

\subsubsection{Sponges with different life strategies host different bacterial populations}

Demosponge microbiologists have contrasted species that form dense and phylogenetically complex microbial communities (HMA or high microbial abundance) against those that contain only few and less diverse microbes of essentially non-specific types (LMA or low microbial abundance), representing two different basic life strategies (Weisz et al., 2008). HMA sponges typically have a reduced aquiferous system with lower pumping rates, while LMA sponges have highly porous tissues with high pumping rates that enable rapid uptake of small particulate organic matter, yet the nitrification/denitrification rates remain comparable (Schlappy et al., 2010). Calcareous sponges have been comparatively less studied as regards their bacterial flora. Quévrain et al. (2009) and Roué et al. (2010) found that two North Atlantic calcareous species had a stable bacterial population throughout the year.

\subsubsection{Specificity, host selectivity and vertical transmission to offspring}

Bacterial associations may range from non-specific commensalism to species-specific symbiosis, with some intracellular or even endonuclear examples which are more common in protistan hosts than in metazoans in which they are regarded as signs of a very ancient association (see Hoyos, 2010). In sponges (Vacelet, 1970; Friedrich et al., 1999), such intranuclear examples are found in the genus Aplysina. More commonly, the existence of 
core-consortia of bacteria which are found in distant conspecific sponge populations and all year around indicates a high degree of functional specificity and species selectivity. Vertical transmission of "essential" bacteria from parent to offspring via the eggs or the larvae in, respectively, oviparous and ovoviviparous species have been investigated by Webster et al. $(2010 b)$ in major poriferan clades: Demospongiae, Homoscleromorpha, Calcarea and Hexactinellida (Ereskovsky, 2011), also including cyanobacteria (Usher et al., 2001).

\subsubsection{Other components of the sponge holobiont}

Archaea are found in a wide variety of sponges, and their populations have been characterized in several taxa, e.g. Axinella, either as clade-specific mutualists or not, with some sponges lacking them altogether (Holmes \& Blanch, 2007). This understudied component is primarily involved in ammonia oxidation, but the co-production of bioactive metabolites is not excluded.

In addition, sponges are host to microscopic algae, viruses, yeast and fungi, which add to the biodiversity and, at least for the fungi, to the chemodiversity of the holobiome (e.g. König et al., 2006). Sponges are host to a strain of Aspergillus sydowii, a fungus which has been identified as a causative agent of epidemics that affect gorgonian corals. The authors of the study (Ein-Gil et al., 2009) postulate that sponges may act as reservoirs of potential marine pathogens, in the same way as the bacterial populations associated with turf and macroalgae are considered as potential sources of infection to scleractinian corals which are host to specific microbiomes (Barott et al., 2009).

Polychaetes, prosobranchs, ophiuroids and crustaceans are also commonly found in association with sponges, and the disappearance of the latter would automatically reduce the specialized associated invertebrate biodiversity.

\subsection{The sponge holobiont - Functional aspects}

The sponge microbiome is a prime example of natural chemodiversity, occupying an extensive range of functions in primary ( $\mathrm{C}$ and $\mathrm{N}$ cycling - see e.g Li, 2009) and secondary metabolism (thousands of original molecules of various classes and modes of action) which has been studied worldwide by natural product chemists.

\subsubsection{Functional "primary" aspects of symbiosis}

The biochemical nature of sponge-microbe symbioses is largely unknown, and ideally requires investigations at single strain microniche consortium and whole microbiome levels (Kamke et al., 2010) for a given host to obtain a better insight into the functional dynamics of the holobiont. Several basic (primary metabolism) sponge-associated microbial processes have been described, including:

i. nitrification, the oxidation of ammonia $\left(\mathrm{NH}_{3}\right)$ to nitrite $\left(\mathrm{NO}_{2^{-}}\right)$and subsequently to nitrate $\left(\mathrm{NO}_{3^{-}}\right)$for energy purposes, both steps being carried out by two different bacterial groups: AOB or ammonia oxidizing bacteria and archaea, and NOB or nitrite oxidizing bacteria (Bayer et al., 2008),

ii. nitrogen fixation which appears important in nutrient poor reef environments (Mohamed et al., 2008). Recently Hoffman et al. (2009) described the complex nitrogen cycle of the sponge Geodia barretti and speculated upon the possible role of marine sponges as nitrogen sinks,

iii. photosynthesis with cyanobacteria (Arillo et al., 1993; Li., 2009) and even zooxanthellae that appear to resist elevated temperatures (but not light) better than coral 
zooxanthellae (Schönberg et al., 2008) and when present actively contribute to carbon supply to the host (Weisz et al., 2010),

iv. methane oxidation (Vacelet et al., 1996) and sulfate reduction (Hoffmann et al., 2005).

\subsubsection{Communication "secondary" aspects of symbiosis}

So-called secondary metabolites may be produced and released according to age and reproductive status, but also as a response to abiotic and biotic stresses, against predation and microbial infection, for resource defense against competitors, etc. The communication chemistry of soft-bodied sessile invertebrates can indeed be regarded as a vocabulary of molecular words, and its transcriptomics can be equated to proper syntax, in order to respond as exactly and as economically as possible to an identifiable conflict. According to their mode of action, these molecules can be volatile (short MW halocarbons), surface or tissue bound, or mucus-borne. The participation of the microbiome to the biosynthesis of sponge metabolites has been established in a number of cases in natural conditions, but cultivated individual strains or functional consortia of interest may not express the desired phenotype (production of a specific molecule), or may not be cultivatable outside their host. Aside from possible applications in human welfare, bacteria provide prime examples of prokaryote-metazoan coevolution which have endured an estimated 600 million years of existence and survived major biogeoclimatic changes.

The sponge mesohyl provides a broad variety of ecological microniches that host bacterial consortia (Thiel et al., 2007), with varying degrees of dependence to the host, while cortical regions tend to be dominated by cyanobacteria (Li, 2009). Both components are known to be involved in the synthesis of bioactive secondary metabolites which are naturally produced (or prompted) in response to microbial pathogens (antibiotics), space competitors (allelopathic substances), epibionts (antifouling molecules), and predators (antifeedants, intoxicants, serine protease inhibitors). This chemical arsenal, together with the presence of structural (sharp mineral sclerites, or tough spongy texture) and visual (warning or cryptic colors and patterns) defenses, are necessary to the survival of these non-motile and often exposed invertebrates. Most classes of so-called secondary metabolites are represented, making sponges a treasure trove for the discovery of new drugs. Here we are concerned with the global chemodiversity aspect and the reader is prompted to consult updated reviews (for example in the dedicated issues of Natural Products Reports since 1977), or texts such as Kornprobst (2010b) that provide a user-friendly review of sponge-derived metabolites, addressing their possible biosynthetic origins and their potential applications. Metagenomic screening to identify key polyketide synthase (PKS) and non-ribosomal peptide synthetase (NRPS) genes, and new cloning and biosynthetic expression strategies may provide a sustainable method to obtain new pharmaceuticals derived from the uncultured bacterial symbionts, e.g. with cyanobacteria ( $\mathrm{Li}$, 2009). Novel culturing techniques (e.g. Selvin et al., 2009), including co-culturing of microorganisms modulating the proliferation (through quorum sensing) and the expression of strains of interest are now actively investigated (Dusane et al., 2011).

\section{Reef-building corals}

\subsection{Scleractinian corals as reef architects}

Scleractinian corals present a rich fossil record dating back approximately 240 million years, i.e. they appeared much more recently than macroalgal lineages ( 1 billion years) and also than sponges (600 million years). 
About half of the 1,300 scleractinian coral species are reef-building, largely colonial, zooxanthellate (hermatypic) and occurring in the clear, shallow and oligotrophic waters of the tropics. The other half of the order is largely solitary and azooxanthellate, occurring in all regions of the oceans, including the greatest depths (Budd et al., 2010). The reef-building corals function as primary ecosystem engineers, constructing the framework that serves as a habitat for all other coral reef-associated organisms (Wild et al., 2011). Scleractinians are actively engaged in the production and transformation of mineral and organic materials. Coral limestone structures are broken down by bioeroding organisms and abiotic processes into sand, itself acting as a natural biocatalytic filter for the cycling of organic matter by resident heterotrophic microorganisms (Wild et al., 2005).

\subsection{The coral holobiont: An example of 3-way functional integration}

The term holobiont, sometimes collectively defined as biota engaged in a host-symbiont partnership (Santiago-Vázquez et al., 2006), has been borrowed by coral researchers to conveniently include the coral host and all of its associated interactive life forms (reviewed in Rohwer, 2010). This includes tissue-associated symbiotic photosynthetic microalgae, surface and mucus-dwelling bacteria and archaea (Siboni et al., 2008) and recently investigated viruses (Vega Thurber, 2008). Endolithic algae and fungi that bore into the mineral skeleton (Wegley et al., 2004) may be included in this definition as permanent associates (as in Bourne et al., 2009). Very recently a true symbiotic relationship has been described between the acroporid Acropora muricata and the hydrozoan Zanclea margaritae (Pantos \& Bythell, 2010). "Mobile" associates (crustaceans, mollusks, polychaetes etc.) provided they have developed a specific niche or trophic preference with the host and developed a cryptic or aposematic appearance as a result, should logically be included in this definition in that the host's disappearance would probably signify a loss of this additional biodiversity.

The coral holobiont is now regarded as a functional unit by scientists who are interested in physiology, pathology, biochemistry and environmental issues of reef-buiding anthozoans. A review of the functional microbiota associated with corals is provided by Laming (2010). Fig. 1 illustrates the typical coral holobiont with its associated macro- and micro-organisms.

\subsection{The coral holobiont on autotrophic, heterotrophic and mixotrophic feeding modes} Mixotrophic organisms can functionally combine different modes of nutrition: (i) by using photosynthesis for inorganic carbon fixation; and (ii) by taking up organic sources. Coral polyps are diploblastic and hence have no mesoderm-derived digestive tract or specialized respiratory organ. Nutrient and energy requirements of the whole colony must depend (i) on direct diffusion of dissolved gases and simple organic molecules across the polyp body wall, (ii) on "assisted metabolism" with pseudo-respiratory and pseudo-digestive functions in association, respectively, with symbiotic macroalgae sequestered in the endoderm, and mucus-bound bacterial consortia, (iii) during the night, on heterotrophy, i.e. ingestion of bacteria and planktonic particles that are digested in the coelomic cavity, the organic products being further broken down by other bacteria. During the day, polyps function in autotrophic mode, i.e. relying on oxygen production and carbon photosynthates provided by the symbiotic zooxanthellae. Other commensal members of the "extended" holobiont, i.e. crustaceans, echinoderms, polychaete worms, mollusks, etc., live mostly off the food particles trapped in the coral mucus, or as parasites. 


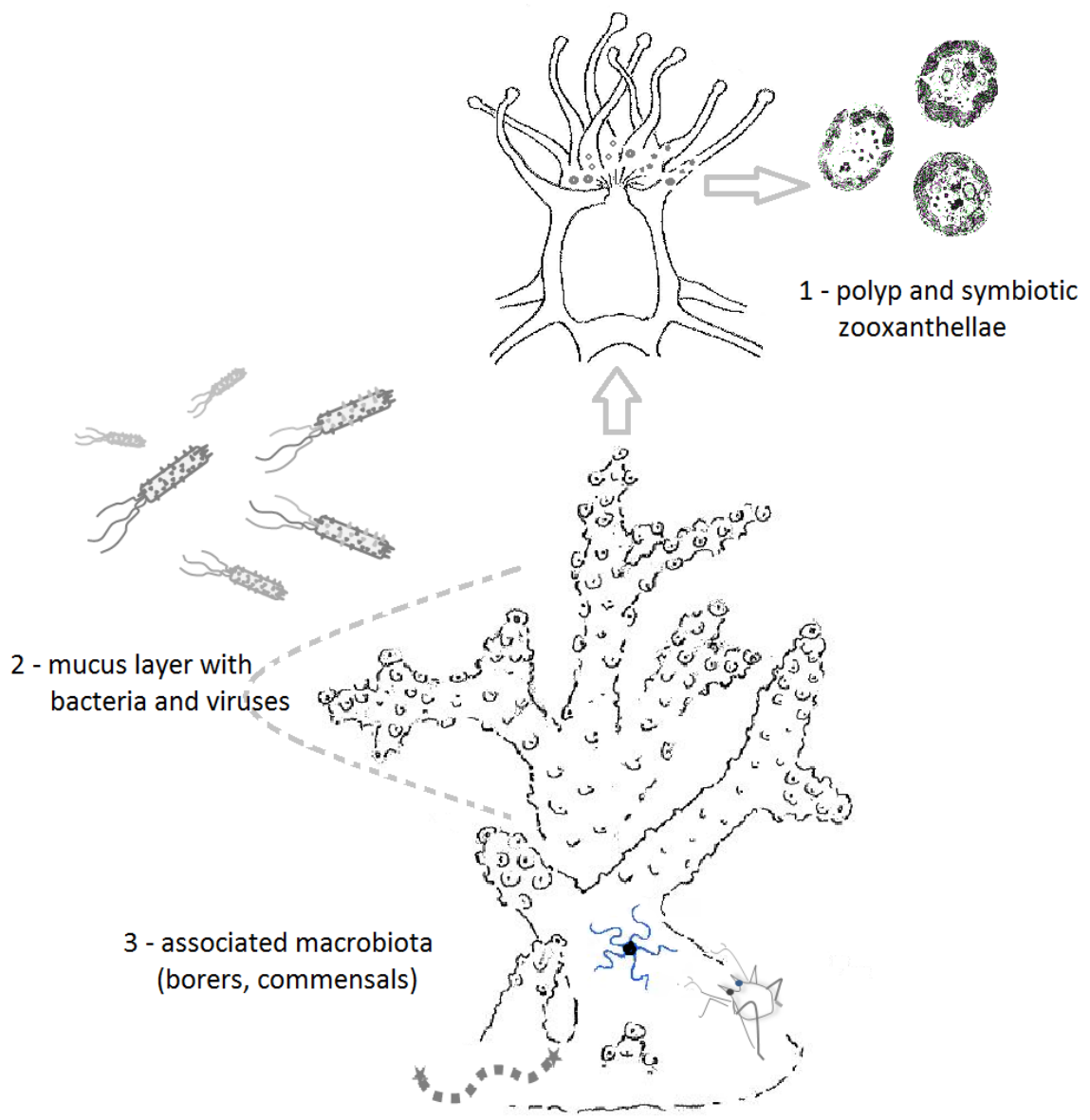

Fig. 1. Schematic representation of a typical coral holobiont.

1- The polyp endoderm harbors symbiotic dinoflagellates (various clades of the genus Symbiodinium), i.e. the zooxanthellae; 2- polyps produce copious amounts of mucus, a multifunctional interface with the outside world, in which bacteria and viruses are trapped together with food particles; 3- associated organisms that have a permanent (non-mobile forms) or an obligate (mobile forms) relationship with the host.

\subsubsection{Direct assimilation of DOM (dissolved organic matter)}

This mode of nutrient acquisition is commonplace in benthic diploblastic organisms. It has also been experimentally demonstrated in sponges (de Goeij et al., 2008), while plankton capture is the most commonly described method for filter feeders in open waters, while POM (particulate organic matter) feeding is generally regarded as assimilation of POM bacterial degradation products. To the holobiont, bacteria are as important in nitrogen fixation as zooxanthellae are in carbon fixation. Corals are opportunists in their nitrogen acquisition modes, as its sources are capable of fluctuating rapidly in an oligotrophic environment. Polyps are capable of absorbing dissolved amino acids non-discriminately 
through a photosynthesis-enhanced (i.e. daylight) mechanism, thus providing about one quarter of the polyp's nitrogen requirements (Grover et al., 2008), while dissolved ammonia, nitrate and urea make up for nearly all of the remaining needs. In another study (Fitzgerald \& Szmant., 1997) consider that corals can "synthesize" 16 of the 20 amino acids (including the eight regarded as essential), meaning that bacteria metabolize them from degrading mucus and that the coral readily absorbs the amino acids. Agostini et al. (2009) have shown that a resident bacteria produce B12 vitamin that is taken up by the coral in the coelenteron. The zooxanthellae are fertilized with the inorganic nitrogenous and phosphate excreta of the polyp as well as obtaining a sheltered niche in exchange for their essential role in functional maintenance of the holobiont. This feature of acclimatization (nitrogen capture) is considered important in a fluctuating environment (Gates \& Edmunds, 1999). Finally, scleractinians are potentially capable of modulating their epibiotic bacterial community by producing antibacterial compounds as part of a constitutive defense mechanism, as demonstrated in alcyonarians by Harder et al., (2003), and a feature shared by other marine diploblastic invertebrates investigated for their pharmacological potential. The detection of QS signals in coral-associated microbiota (Goldberg et al., 2011) might explain the role of the bacterial component in the holobiont dynamics. Bacterial colonization may indeed be modulated at strain-level by molecules produced by the coral host and interfering with intraspecific (Gram - AHL and Gram + AIP) or interspecific (AI-2) QS inducers.

\subsubsection{Respiration and translocation of photosynthates}

The carbon requirements for respiration in branching and foliose corals are essentially provided by carbon dioxide fixation by the algal symbiont (Muscatine \& Cernichiari, 1969) during daytime photosynthesis. Under normal conditions subsurface branched corals acquire up to $95 \%$ of their energy requirements by coupling their primary metabolism with that of their symbiotic zooxanthellae, which perform carbon fixation and provide other shared benefits, e.g. mucus production.

\subsubsection{Food capture and extracoelenteric digestion}

Food capture of nano- and macro-plankton, especially bacteria and zooplankton, affords the heterotrophic alternative to most corals, i.e. it helps with acquisition of other elements that are essential to the functioning of the holobiont, including that of the bacterial compartment. In addition, heterotrophy enables calcification by providing the elements of the organic matrix upon which carbonate biomineralization is initiated. Furthermore, feeding rate is enhanced in bleached corals. Switching between autotrophic and heterotrophic modes of feeding has been investigated by Houlbrèque \& Ferrier-Pagès (2009).

Evidence of coelenteric digestion in hermatypic corals has been long been documented (Boschma, 1925) and extracoelenteric digestion has been suggested in some corals to be a strategy to defend space from competing neighbours (Lang, 1990).

\subsubsection{Mucus and mixotrophic metabolism}

Coral mucus represents a major metabolic investment on behalf of the coral (up to half of its carbon budget), and it actively contributes to the carbon budget of coral reef systems by bringing photosynthates and trapped organic matter to lagoon sediment where heterotrophic nutrient recycling operates efficiently (Wild et al., 2004). To the colony, mucus is used primarily for protection against silting (layers are sloughed off regularly) and against 
dessication at low tide, as well as acting as natural sunscreens since they concentrate UVabsorbing mycosporin-like amino acids (MAAs) produced by the zooxanthellae (Dunlap \& Schick, 1998). Mucus is also used to entrap food particles (plankton and POM) which are then drawn into the endodermal sac by the tentacles. Mucus is also an obvious source of carbon to many bacteria that degrade it and use it as a dispersion vector, somewhat like bacterial biofilm streamers (Allers et al., 2008). Solitary corals (e.g. Fungia) may even asphyxiate and poison their competitors by emitting thick mucus layers that cover neighboring colonies. A comprehensive review on the nature and multiple roles of coral mucus has been proposed by Brown \& Bythell (2005), who hypothesize that the intraspecific composition of coral mucus is not homogenous and that different types of mucus may be produced according to needs and environmental stressors. Chemically, coral mucus is a polysaccharide-protein-lipid complex secreted by corals at their surface (ectodermal goblet cells), and there are as many different types of mucus as there are types of corals. Carbohydrate photosynthates are produced at a fast rate as the major component of the mucus which is essential to the whole colony as an exchange medium. In addition to serving as food to polyps in oligotrophic waters, mucusassociated bacterial consortia appear to be an essential component for the recycling of waste and for the biosynthesis of molecules that are useful as osmocompatibles, ROS (reactive oxygen species) detoxicants, anti UV sunscreens, biogeochemical sulphur cycling, etc.

\subsection{Biomineralization in reef-building corals}

In corals and in mollusks, extracellular mineral structures develop upon a matrix derived from secretory products of calicoblastic tissues. This phosphate-rich 3-D matrix is typically made up of acidic proteins, carbohydrates and glycoproteins, and is genetically programmed to perform essential regulating and/or organizing functions that will result in the formation of composite biominerals (Weiner \& Dove, 2003). The latter are formed as outer membranes release the cationic elements that are taken up intracellularly and delivered / diffused to the matrix where they may be orderly arranged with organic components (e.g. in oyster nacre). There has been some debate about the role of photosynthesis in the calcification process of corals, but light is certainly not a prerequisite for the calcification process. There is substantial evidence for a diurnal cycle in the coral calcification and skeleton-building process during which the types of crystals deposited, their distribution about the skeletal surface and the overall rate of calcification changes (Cohen \& McConnaugh, 2003). Central to these changes is the bimodal functioning of the light-sensitive $\mathrm{Ca}^{++}$- ATPase pump that has the dual role of transporting cations into the calcifying space while removing protons. On site mineralization is probably initiated at sulfated sites of exopolysaccharides, with crystal growth possibly "guided" by organic processes at the interface with the calicoblastic epithelium (Cohen \& Mc Connaugh, 2003). An up-to-date treatment on the subject of cellular mechanisms of scleractinian coral calcification is provided by Reyes-Bermudez (2009).

\subsection{Scleractinian responses to environmental changes}

In contrast to the aforementioned "regular" and transient biotic and abiotic events that may contribute to the classical Darwinian view of evolution and biodiversity, the multifaceted consequences of the rise in atmospheric carbon dioxide (aggravated by industrialization) on coral reefs are now estimated to be the primary cause of massive losses of reef-associated biodiversity within the next decades. 
Drastic changes in the "regular" holobiont microbiodiversity, gradual loss of physiological functions and cell/tissue damage beyond recovery, are generally regarded as an aggravation of naturally existing challenges of the holobiont system, due to an unfavorable biogeochemical evolution of the environment.

Research now focuses on how ocean warming and acidification can lead to rapid coral mortality and affect biodiversity quantitatively and qualitatively, especially in humanimpacted areas. Coral bleaching, i.e. loss of the symbiotic microalgal partner, skeletal demineralization, and also effects on larval and juvenile stages and disease susceptibility to pathogens, are the central themes of most of the reef-building coral literature published since 1998. Parallel to stress and mortality studies, investigators report examples of species, communities, habitats or geographical areas that actually resist or acclimatize to e.g. repeated bleaching, whether generated by biotic or abiotic factors.

\subsubsection{Scleractinians and thermal stress}

Bleaching (discoloration) is due to the rupture of the resident Symbiodinium algae with their coral host, due to mortality, loss of pigments or expulsion (Brown, 1997). Decrease in uptake and endodermal sequestration of photosymbionts may be a response to mutual perception of toxic levels of reactive oxygen species (ROS) during enhanced light-induced photosynthesis (Vidal-Dupiol et al., 2009). Coral holobiont resilience to thermal stress was extensively discussed by Coles \& Brown (2003) in the light of twenty years of worldwide short- and long-term observations on various types of corals. Reef organisms are stenotolerant to heat, with tolerance limits usually not exceeding $31-32^{\circ} \mathrm{C}$ for branched acroporids before significant mortality occurs (Berkelmans \& Willis, 1999), a range similar to that of sponge tolerance limits in the same locality of the Australian Great Barrier Reef (Webster et al., 2008). Other localities have selected for coral communities that are adapted to their climatic regime. In the Red Sea and the Arabian Gulf, the ambient summer seawater temperature reaches $34-36^{\circ} \mathrm{C}$. In general, increases of $1-3^{\circ} \mathrm{C}$ above mean long-term annual maximum temperature have consistently induced coral bleaching.

Recovery is very much species-specific in shallow water scleractinians. Skeletal drillings of hundreds of years old massive forms (e.g. Porites) provide records of severe climatic events which colonies have survived (Cleveland et al., 2004). Physiological and cytological adjustments concern the protection of the light-harvesting complex from solar photosynthesis-active radiation (PAR) and ultraviolet radiation (UVA and UVB), and against overheating. Excessive PAR over-stimulates photosynthesis with production of cytotoxic reactive oxygen species (ROS), and UV radiations are genotoxic, while infrared radiations (IR) cause thermal stress.

Mechanisms allowing acclimatization to elevated seawater temperatures include activation of the xanthophyll cycle as a photoprotective defence (dissipation of PAR as heat), induction of heat-shock proteins and antioxidant enzymes, and the production of mycosporin-like amino acid sunscreens. The photoprotective role of GFP-like fluorescent pigments in scleractinian polyps has been established both in the visible light range (dissipation of PAR through fluorescence and light diffraction), and in the UV range (transformation of UVA radiation into longer-range non actinic fluorescence), in order to protect the algal symbiont chlorophyll and peridin from photo-oxidative damage (Salih et al., 2000). The peroxidasemediated production of reactive oxygenated species (ROS) is an initial response against abiotic stress and microbial pathogens, also observed in corals. Palmer et al. (2010) have 
shown that components of the immune system of corals respond to oxidative stress by activating phenoloxidases (PO) and laccase activities on-site, with the production of melanin (in addition to GFP-like pigments). Akin to algal phlorotannins, melanin and other putative antioxidants play a role in wound healing and oxidative stress mitigation, as well as pathogen encapsulation (Mydlarz \& Palmer, 2011). Indeed, PO activity levels, melanin abundance and distribution and GFP-like pigments may serve as useful descriptors of susceptibility to environmental changes in shallow water scleractinian corals (Palmer et al. 2010). Overall, long-lived massive coral growth forms appear better equipped to withstand transient stress than short-lived and more delicate branched forms (Palmer et al., 2011).

A shift in the composition of resident Symbiodinium microadriaticum zooxanthellae from stenotolerant to thermoteolerant clades may occur following short bleaching episodes. Indeed, this "upgrading" is the basis of the adaptive bleaching hypothesis or ABH (Kinzie et al., 2001), according to which the bleached basibiont can select a clade better suited to a momentary environmental disturbance.

Another strategy against bleaching is to increase heterotrophy as a source of food energy to compensate for loss of light-derived photosynthates, in species equipped with functional food capture devices.

\subsubsection{Scleractinians corals and seawater acidification}

The increase in $\mathrm{pCO}_{2}$ in the water column leads to an increase in total dissolved $\mathrm{CO}_{2}$ at the expense of carbonate ions $\left[\mathrm{CO}_{3}{ }^{2-}\right]$. The reduction in the latter, at constant seawater calcium concentration $\left[\mathrm{Ca}^{2+}\right]$, consequently results in the decrease of the saturation state of aragonite $\left(\Omega_{\text {arag }}\right)$, the polymorph of $\mathrm{CaCO}_{3}$ produced by coral calcification (Wild et al., 2011). Aragonite super-saturation is necessary for efficient accretion in most scleractinians, and a lowered external $\Omega_{\text {arag }}$ will impede the calcification rate in internal fluids and crystal formation at the calicoblastic/seawater interface, translating into weaker skeletons and general deterioration in reef habitat construction. By the year 2100, $\Omega_{\text {arag }}$ is expected to decrease from an average value of 4 (necessary for calcium accretion) to less than 3 (insufficient for most shallow-water branching corals). Together with natural bioerosion, decalcification may breakdown entire reef constructions in time. Along with decalcification, the lowering of seawater $\mathrm{pH}$ causes a shift in the bacterial microbiodiversity, in favor of the most resilient strains, some of which are typically associated with stressed and diseased corals, e.g. Vibrionaceae and Alteromonadaceae (Meron et al., 2011).

\subsubsection{Scleractinian corals, anoxia and eutrophication}

Shallow water colonial corals thrive in pristine oligotrophic waters, with a finely tuned carbon and nitrogen metabolism as long as the associated microalgal and bacterial flora remains unaffected.

Nutrient enrichment generally occurs close to human settlements and is therefore likely to first affect fringing reefs. Experiments using media artificially enriched with inorganic ions $\left(\mathrm{PO}_{4}^{-}\right.$and $\left.\mathrm{NO}_{3}^{-}\right)$have shown that the release of dissolved organic carbon and of dissolved organic nitrogen actually decreased relative to tissue surface area in the test species Montipora digitata thus affecting not only the efficiency of the photobiosis, but also the mucus-feeding bacteria (Tanaka et al., 2010). However, the counterbalancing combination of eutrophication and seawater warming generates stress to the coral colony, setting the stage for a change in the metagenomic profile of bacteria from functional and diverse to 
pathogenic and restricted. Webster \& Hill (2007) have reviewed ways into which the microbial life of the Great Barrier Reef ecosystems may be impacted by global warming. Along these lines, Ainsworth et al. (2009) have predicted a "microbial perspective" for coral reefs in the next decades, and proposed the addition of a metagenomic component in building predictive models.

\section{Conclusion: Towards an integrative approach}

Since mild episodes of adverse climatic and biotic conditions regularly occur, it can be assumed that coral reefs are quite resilient with respect to biodiversity losses. Today, human activities are having a steadily increasing impact on climate (global warming) and on biodiversity (overexploitation and toxic waste) and although accurate predictions cannot be made, it is assumed that massive losses of marine biodiversity associated with coral reefs will occur within the next decades. The capacity of organisms to acclimatize and that of communities to maintain their biodiversities is largely unknown, and estimates are based on isolated laboratory experiments in which tolerance limits to individual stressors are measured. The spread of microbial diseases from the shallow $(0-30 \mathrm{~m})$ to the mesophotic (30 - $200 \mathrm{~m}$ ) zones has been discussed by Olson \& Kellogg (2010) who prompt investigations on the algal, sponge and coral holobionts from the hitherto neglected deeper reef communities. At the holobiont level, it is important to detect early signs of stress (e.g. coral bleaching due to loss of zooxanthellae) and to identify the critical stages beyond which permanent damage results (e.g. tissue necrosis, various band diseases due to microbial pathogens). Intraspecific variations in the profiles of bacterial communities associated with corals may show up between distant localities (Littman et al., 2009), suggesting that environmental conditions may significantly influence the dominance profiles of a few strains, possibly reflecting on the health status of the host species. At the community and ecosystem levels, it is important to evaluate the extent of damage and whether recolonization is possible if the primary cause can be removed (e.g. by classifying an impacted area as a protected zone). Along the same lines, it should now be possible to devise molecular-based methods that can accurately estimate a shift in bacterial biodiversity from standard to pathogenic in a given sample, to estimate stress levels, or to compare metabolomic signatures between unaffected and impacted specimens. Comparable methods already exist in medical microbiology, and in cancerology in which specific markers are sought in addition to metabolomic profiling of biological fluids.

\subsection{The common fate of biodiversity and chemodiversity}

Biodiversity emerged as the first unicellular forms of life appeared, presumably as chemoautotrophs in hydrogeothermal environments. The original biogeochemistry was quite different to what it is today, and different mineral-water-air equilibria must have been attained several times since the emergence of life, e.g. basic Precambrian vs. acidic modern ocean (David \& Alm, 2011). As biodiversity and chemodiversity increased, their influence on global biogeochemistry gradually increased (Falkowski et al., 2008). Cyanobacteria are thought to have enriched the atmosphere in oxygen to the point that through various endosymbiosis scenarios a "compromise" was reached that allowed living entities to use oxygen generated by photosynthesis for respiration while controlling its toxicity. Taming the generation of highly reactive radical oxygen species by using oxidative stresses as useful 
warning signals of an environmental aggression is an example of this adaptation to aerobic life. Competition between an ever-increasing number of species and ever reducing availability of resources fueled a new form of chemodiversity, that of secondary or communication metabolites. Thus, the biochemistry involved in physiological adaptation and inter-organism communication links biodiversity and chemodiversity. This simplified picture does not account for the contribution of microorganisms to both primary and secondary metabolisms of the host they live with. In aquatic environments, attempts to integrate all biotic communities participating in the same functional dynamics gave rise to the hologenome theory and to the holobiont concept. When addressing environmental issues, and especially stress responses, this new biome approach can benefit from the fast evolving molecular and genomic fields of metabolic fingerprinting and microbial metagenomics, in the quest for suitable analytical tools. Recent culture-independent approaches have revealed an unsuspected quantity of microbial diversity, not only bacterial (Sogin et al., 2006), but also eukaryotic (Dawson \& Hagen 2009), the "rare biosphere", representing a potential reservoir of genes and genomes that marine life may rely on to adapt to new environmental conditions.

\subsection{Intellectual diversity should work for, not against natural diversity}

Man has been impacting his environment with extensive use of metals since the onset of the 19th century industrial era. Artificial chemodiversity followed, due to the development of the petroleum chemistry, synthetic polymers and new pharmaceuticals. Unfortunately, the industry has shortsightedly released into the environment thousands of novel organic molecules without proper evaluation of allergenic and carcinogenic effects on human health, both by direct exposure or through accumulation in terrestrial and aquatic food chains. Degradability and speciation of industrial and household waste have been neglected, with destruction of entire fragile ecosystems e.g. rivers and ponds. Biodiversity has also been "directed" with an increasing number of selected crop plants and farm animals and now with genetically modified versions which can arguably hybridize and displace natural conspecifics. The coming of age of bioresponsibility vs. exploration may soon become a necessity, i.e. what can be collectively termed as intello-diversity must be applied to the uptake of acceptable practices for the maintenance of a balanced natural equilibrium while making resources lasting and renewable.

\subsection{How can scientists mediate environmental conflicts and help political action}

At present, research concentrates on a handful of "convenient" model reef species and on how their metabolism reacts to experimental disturbances. This approach is of limited use outside the confines of the laboratory. To be applicable to real-life situations, i.e. mining pollution in an otherwise undisturbed environment, multi-scale studies must be undertaken. In the laboratory, stress studies must not only concentrate on the transcriptomics of stress-associated genes of the host organism, but should also include assessment of accompanying changes of the microbiodiversity which is likely to reveal a profile change from functional to pathogenic, and from autotrophic to heterotrophic (Littman et al., 2011). New molecular tools could be developed to address all types of environmental issues, ranging from specific toxicity to geoclimatic changes, including urban or industrial pollution. For example, spotting out the "sentinel" bacteria strain in an ecologically sensitive holobiont would provide a quantifiable biomarker of an 
environmental disturbance. The more specific its reactivity to a specific stress, the better. The logic behind this approach is similar to extracting the chemical profile of a marine invertebrate from an impacted environment and comparing it with the profile database of a conspecific from a pristine environment, and hopefully identifying a chemical marker that would act as a signature (as in clinical analyses of body fluids and the search of specific markers of cancer). The association of biological and chemical profiling and signature marking into a standardized procedure would undoubtedly help industry deciders to evaluate the importance of environmental impacts and to take appropriate action. At an intermediate scale, in-situ monitoring of key environmental parameters in mesocosms allows modeling that is useful for decision-making in creating natural reserves. Respecting protected reef areas should be a mature political decision based on sound scientific investigations. For example, active nickel mining and ore processing in the immediate vicinity of coral reefs protected under the UNESCO's World Heritage list in New Caledonia generates difficult choices between short-term economic profit and long-term and durable exploitation of reef resources.

Finally, accessible information through the media and adapted and participative school programs should be encouraged in order to modify the management of reef resources to take into account sustainable and durable applications.

\subsection{Biodiversity beyond ecosystem resilience - What's next?}

Joseph Connell's summary of his landmark Science paper of 1978 emphasizes the necessity to maintain some kind of equilibrium between human activities and natural environments, a condition without which very large clusters of biodiversity may be irremediably lost:

"The commonly observed high diversity of trees in tropical rain forests and corals on tropical reefs is a nonequilibrium state which, if not disturbed further, will progress toward a low-diversity equilibrium community. This may not happen if gradual changes in climate favor different species. If equilibrium is reached, a lesser degree of diversity may be sustained by niche diversification or by a compensatory mortality that favors inferior competitors. However, tropical forests and reefs are subject to severe disturbances often enough that equilibrium may never be attained." Joseph Connell (1978)

Life would then have to re-create itself in unforeseeable evolutionary scenarios, counting on the inventiveness and adaptability of the microbial world where man's inventiveness will have failed.

\section{Acknowledgment}

I am very grateful to Dr. Ian Probert for his critical reading of the manuscript and for checking the English, and to Prof. Jean-Michel Kornprobst for useful suggestions.

\section{References}

Ainsworth, T.D.; Vega Thurber, R. \& Gates, R.D. (2009). The future of coral reefs: a microbial perspective. Trends in Ecology and Evolution Vol.25 No.4, pp. 233-240, ISSN: 01695347

Agostini, S.; Suzuki, Y.; Casareto, B.E.; Nakano, Y.; Hidaka, M. \& Badrun, N. (2009). Coral symbiotic complex: Hypothesis through vitamin B12 for a new evaluation. Galaxea, Journal of Coral Reef Studies Vol. 11, pp. 1-11, ISSN: 1883-0838 
Alegado, R.A., Kontnik, R.; Fairclough, S.R.; Zuzow, R.; Clardy, J. \& King, N. (2010). A bacterial sphingolipid induces choanoflagellate colony development. 3rd Conference on Beneficial Microbes. Oct 25-29, 2010 Miami Florida. American Society for Microbiology.

Allers, E.; Niesner, C.; Wild, C. \& Pernthaller, J. (2008). Microbes enriched in seawater after addition of coral mucus. Appl. And Environ. Microbiol., Vol.74, No10, pp. 3274-3278, ISSN: 0099-2240

Arillo, A.; Bavestrello, G.; Burlando, B. \& Sarà, M. (1993). Metabolic integration between symbiotic cyanobacteria and sponges: a possible mechanism. Marine Biology, Vol.117, pp. 159-162, ISSN: 0025-3162

Azam, F. \& Malfatti, F. (2007). Microbial structuring of marine ecosystems. Nature Reviews Microbiology, Vol.5, pp. 782-791, ISSN: 1740-1526

Ball, S.; Hollingsworth, A..M.; Humble, J.; Leblanc C.; Potin P. \& Mc Figgans G. (2010). Spectroscopic studies of molecular iodine emitted into the gas phase by seaweed. Atmos. Chem. Phys.,Vol.10, pp. 6237-6254, ISSN: 1680-7316

Barott, K.; Smith, J.; Dinsdale E.; Hatay, M.; Sandin S. \& Rohwer F. (2009). Hyperspectral and physiological analyses of coral-algal interactions. PLOS ONE, Vol.4, No4, e8043, pp. 1-9, ISSN: 1932-6203

Bayer, K.; Schmitt, S. \& Hentschel, U. (2008). Physiology, phylogeny and in situ evidence for bacterial and archaeal nitrifiers in the marine sponge Aplysina aerophoba. Environ. Microbiol., Vol.10, No.11, pp. 2942-2921, ISSN: 14622912

Bensoussan, N. \& Gattuso, J-P. (2007). Community primary production and calcification in a NW Mediterranean ecosystem dominated by calcareous microalgae. Mar. Ecol. Prog. Ser. Vol.334, pp.37-45, ISSN: 0171-8630

Bentov, S.; Brownlee, C. \& Erez, J. (2009). The role of seawater endocytosis in the biomineralization process in calcareous foraminifera. PNAS, Vol.106, No51, pp.21500-21504, ISSN: 0027-8424

Berkelmans ; R. \& Willis, B.L. (1999). Seasonal and local spatial patterns in the upper thermal limits of corals on the inshore Central Great Barrier Reef. Coral Reefs, Vol.18, pp. 219-228, ISSN: 0722-4028

Blackford, J.C. (2010). Predicting the impacts of ocean acidification: challenges from an ecosystem perspective. Journal of Marine Systems,Vol. 81, pp.12-18, ISSN: 0924-7963

Borchardt, S. A.; Allain, E. J.; Michels J. J.; Stearns, G. W.; Kelly, R. F. \& McCoy, W. F. (2001) Reaction of acylated homoserine lactone bacterial signaling molecules with oxidized halogen antimicrobials. Appl. Environ. Microbiol. Vol.67, pp. 3174-3179, ISSN: 0099-2240

Boschma, H. (1925). On the feeding reactions and digestion in the coral polyp Astrangia danae, with notes on its symbiosis with zooxanthellae. Biol. Bull. Vol.49, pp. 407439, ISSN: 0006-3185

Bourne, D.G.; Garren, M.; Work, T.M.; Rosenberg, E.; Smith, G.W. \& Harvell, C.D. (2009). Microbial disease and the coral holobiont. Trends in Microbiology, Vol.17 ,No.12, pp. 554-562, ISSN: 0966-842X

Brawley, S.H. \& Adey, W.H. (1977). Territorial behavior of threespot damselfish (Eupomacentrus planifrons) increases reef algal biomass and productivity. Env. Biol. Fish.,Vol2, No1, pp. 45-51, ISSN: 0378-1909 
Brown , B.E. (1997). Coral bleaching: causes and consequences. Coral Reefs, Vol.16, Suppl. S129-S138, ISSN: 0722-4028

Brown, B.E. \& Bithell, J.C. (2005). Perspectives on mucus secretion in coral reefs. Mar. Ecol. Prog. Ser., Vol. 296, pp. 291, ISSN: 0171-8630

Budd, A.F.; Romano, S. L., Smith, N.D. \& Barbeitos, M.S. (2010). Rethinking the phylogeny of scleractinian corals: a review of morphological and molecular data. Integrative and Comparative Biology, volume 50, number 3, pp. 411-427, ISSN: 1540-7063

Burkepile, D.E. \& Hay, M.E. (2010). Impact of herbivore identity on algal succession and coral growth on a Caribbean reef. PLoS ONE, Vol.5, No1, e8963, ISSN: 1932-6203

Butler, A. \& Carter-Franklin, J.N. (2004). The role of vanadium bromoperoxidase in the biosynthesis of halogenated marine natural products. Nat. Prod. Rep., Vol.21, pp. 181-188, ISSN: 0265-0568

Carballo, J.L. \& Avila, E. (2004). Population dynamics of a mutualistic interaction between the sponge Haliclona caerulea and the red alga Jania adherens. Mar. Ecol. Prog. Ser.,Vol.279, pp. 93-104, ISSN: 0171-8630

Carlton, J.T. \& Geller, J.B. (1993). Ecological roulette: The global transport of non-indigenous marine organisms. Science, Vol.261, pp. 78-82, ISSN: 0036-8075

Carlton, J.T. (1996). Marine bioinvasions: the alteration of marine ecosystems by nonindigenous species. Oceanography, Vol.9, No1, pp. 36-43, ISSN: 1042-8275

Cesar, H.S.J. (2002). Coral reefs, their functions, threats and economic value. http://hdl.handle.net/1834/557

Cesar, H.J.S.; Burke, L. \& Pet-Soede, L. (2003). The Economics of Worldwide Coral Reef Degradation. Cesar Environmental Economics Consulting, Arnhem, and WWFNetherlands, Zeist, The Netherlands. 23pp. Online at: http://assets.panda. org/downloads/cesardegradationreport100203.pdf

Chateau-Degat, M-L; Chinain, M.; Cerf, N., Gingras, S., Hubert . \& Dewailly, E. (2005). Seawater temperature, Gambierdiscus spp. variability and incidence of ciguatera poisoning in French Polynesia. Harmful Algae, Vol.4, pp. 1053-1062, ISSN: 1568-9883

Chisholm, J.R.M. \& Barnes, D.J. (1998). Anomalies in coral reef community metabolism and their potential importance in the reef CO2 source-sink debate. PNAS, Vol.95, pp.6566-6569, ISSN: 0027-8424

Clark, D; Lamare, M. \& Barker, M. (2009). Response of sea urchin pluteus larvae (Echinodermata: Echinoidea) to reduced seawater $\mathrm{pH}$ : a comparison among a tropical, temperate, and a polar species. Marine Biology, Vol.156, pp.1125-1137, ISSN: 0025-3162

Cleveland, R.O.; Cohen, A.; Roy, R.A.; Singh, H. \& Szabo, T.L. (2004). Imaging Coral II: using ultrasound to image coral skeleton. Subsurface Sensing Technologies and Applications,Vol. 5, No. 1, pp. 43-61, ISSN: 1566-0184

Cock, J.M.; Sterck, L.; Rouzé, P.; Scornet, D.; Allen, A. et al. (2010). The Ectocarpus genome and the independent evolution of multicellularity in brown algae. Nature, Vol.465, pp. 617-621, ISSN: 0028-0836

Cohen, A.L.. \& McConnaughey, T.A. (2003). Geochemical perspectives on coral mineralization. In Biomineralization. Eds. P.M. Dove, S. Weiner and J.J. De Yoreo. Mineralogical Society of America, Washington, D.C., v. 54, p. 152-186

Coles, S.L. \& Brown, B. (2003). Coral bleaching - capacity for acclimatization and adaptation. Advances in Marine Biology, Vol.46, pp. 143-183, ISSN: 0065-2881 
Colin, S.; Deniaud, E.; Jam,M.; Descamps, V.; Chevolot, Y.; Kervarec, N.; Yvin, J.-C.; Barbeyron, T.; Michel, G. \& Kloareg, B. (2006). Cloning and biochemical characterization of the fucanase FcnA: definition of a novel glycoside hydrolase family specific for sulfated fucans. Glycobiology, Vol.16, pp. 1021-1032, ISSN: 09596658

Connell, J.H. (1978). Diversity in tropical rain forests and coral reef high diversity of trees and corals is maintained only in a nonequilibrium state. Science, New Series, Vol.199, No 4335, pp. 1302-1310, ISSN: 0036-8075

Cosse, A.; Potin, P. \& Leblanc, C. (2009). Patterns of gene expression induced by oligoguluronates reveal conserved and environment-specific molecular defense responses in the brown alga Laminaria digitata. New Phytologist, Vol. 182, pp. 239250, ISSN: 0028-646X

Crabbe, M.J.C.; Martinez, E.; Garcia, C; Chub, J.; Castro, L. \& Guy, J. (2008). Growth modelling indicates hurricanes and severe storms are linked to low coral recruitment in the Caribbean. Mar. Environ. Res.,Vol.65, pp. 364-368, ISSN: 01411136

David, L.A. \& Alm, E.J. (2011). Rapid evolutionary innovation during an Archean genetic expansion. Nature, Vol.469, pp. 93-96, ISSN: 0028-0836

Dawson, S. \& Hagen, K.D. (2009). Mapping the protistan 'rare biosphere'. Journal of Biology, Vol.8, http://jbiol.com/content/8/12/105

de Goeij, J.M.; Moodley, L.; Houtekamer, M.; Carballeira, N.M. \& van Duyl, F.C. (2008). Tracing 13C-enriched dissolved and particulate organic carbon in the bacteria containing coral reef sponge Halisarca caerulea: evidence for DOM feeding. Limnol. Oceanogr., Vol.53, No4, pp. 1376-1386, ISSN: 0024-3590

Dinsdale, E.A.; Pantos, O.; Smriga, S.; Edwards, R.A.; Angly, F. et al. (2008). Microbial ecology of four coral atolls in the Northern Line Islands. PLoS ONE Vol.3, No2: e1584. doi:10.1371/journal.pone.0001584

Donner, S.D. \& Potere, D. (2007). The inequity of the global threat to coral reefs. BioScience, Vol.57, No.3, pp. 314-215, doi:10.1641/B570302, ISSN 0006-3568

Dusane, D.H.; Matkar, P.; Venugopalan, V.P.; Kumar, A.R. \& Zinjarde, S.S. (2011). Crossspecies induction of antimicrobial compounds, biosurfactants and quorum-sensing inhibitors in tropical marine epibiotic bacteria by pathogens and biofouling microorganisms. Curr Microbiol.,Vol.62, pp. 974-980, ISSN: 1369-5274

Dunlap, W. \& Schick, J.M. (1998). Ultraviolet radiation-absorbing mycosporine-like amino acids in coral reef organisms: a biochemical and environmental perspective $J$. Phycol. 34, 418-430, ISSN: 0022-3646

EPOCA European project (http://epoca-project.eu/)

Ein-Gill, N.; Ilan, M.; Carmeli, S.; Smith, G.W.; Pawlik, J.R. \& Yarder, O. (2009). Presence of Aspergillus sydowii, a pathogen of gorgonian sea fans in the marine sponge Spongia obscura. The ISME Journal, Vol.3, pp. 752-755, ISSN: 1751-7362

Erba, E.; Bottini, C.; Weissert, H.J. \& Keller, C.S. (2010). Calcareous nannoplankton response to surface-water acidification around oceanic anoxic event 1a. Science, Vol.329, p.428, ISSN: 0036-8075

Ereskovsky, A.V. (2011). Vertical transmission of bacteria in sponges. 1st Int. Symp. on Sponge Microbiology, March 21-22, Würzburg, Germany. 
Erwin, P.M., \& Thacker, R.W. (2008). Cryptic diversity of the symbiotic cyanobacterium Synechococcus spongiarum among sponge hosts. Molecular Ecology, Vol.27, pp. 29372947, ISSN: 0962-1083

Fabricius, K. \& De'ath, G. (2001). Environmental factors associated with the spatial distribution of crustose coralline algae on the Great Barrier Reef. Coral Reefs,Vol.19, pp. 303-309, ISSN: 0722-4028

Falkowski, P. (2008). The microbial engines that drive earth's biogeochemical cycles. Science, Vol.320, pp. 1034-1039, ISSN: 0036-8075

Fitzgeral, L.M. \& Szmant, A.M. (1997). Biosynthesis of ' essential ' amino acids by scleractinian corals. Biochem. J. Vol.322, pp. 213-221, ISSN: 0264-6021

Fraune, S. \& Bosch, T.C.G. (2010). Why bacteria matter in animal development and evolution. Bioessays, Vol.32, pp. 571-580. ISSN: 0265-9247

Friedrich, A.B.; Merkert, H.; Fendert, T.; Hacker, J.; Proksch, P. \& Hentschel, U. (1999). Microbial diversity in the marine sponge Aplysina cavernicola (formerly Verongia cavernicola) analyzed by fluorescence in situ hybridization (FISH). Marine Biology, Vol.134, pp. 461-470, ISSN: 0025-3162

Fusetani, N. (2011) Antifouling marine natural products. Nat. Prod. Rep., vol.28, pp. 400-410, ISSN: 0265-0568

Garderes, J.; Henry, J.; Wiens, M. \& Le Pennec, G. (2011). Bacteria-sponge molecular crosstalk: role of quorum-sensing molecules. $1^{\text {st }}$ Int. Symp. on Sponge Microbiology, March 21-22, Würzburg, Germany.

Gates, R.D. \& Edmunds, P.J. (1999). The physiological mechanisms of acclimatization in tropical reef corals. Amer. Zool., Vol. 39, pp.30-43, ISSN: 0003-1569

Gattuso, J.P.; Pichon, M. \& Franckignoulle, M. (1995). Biological control of air-sea $\mathrm{CO}_{2}$ fluxes: effect of photosynthetic and calcifying marine organisms and ecosystems. Mar. Ecol. Prog. Ser., Vol.129, pp. 307-312, ISSN: 0171-8630

Gauna, C.; Parodi, E.R. \& Caceres, E.J. (2009). Epi-endophytic symbiosis between Laminariocolax aecidioides (Ectocarpales, Phaeophyceae) and Undaria pinnatifida (Laminariales, Phaeophyceae) growing on Argentinian coasts. J. Appl. Phycol. , Vol.21, pp. 11-18, ISSN: 0921-8971

Geng, H. \& Belas, R. (2010). Molecular mechanisms underlying Roseobacter-phytoplankton symbioses Current Opinions in Biotechnology, Vol. 21, pp. 332-338, ISSN: 0958-1669

Genovese, G.; Tedone, L., Hamann, M.T. \& Morabito, M. (2009). The Mediterranean red alga Asparagopsis: a source of compounds against Leishmania Marine Drugs,Vol.7, pp. 361-366, ISSN: 1660-3397

Goecke, F.; Labes A.; Wiese, J. \& Imhoff J.F. (2010) Chemical interactions between marine macroalgae and bacteria - a review. Mar. Ecol. Prog. Ser., Vol.409, pp. 267-300, ISSN: 0171-8630

Goldberg, K; Eltzov, E.; Shnit-Orland, N.; Marks, R.S. \& Kushmaro, A. (2011). Characterization of quorum sensing signals in coral-associated bacteria. Microbiol. Ecol. Vol.61, pp. 783-792, ISSN: 0095-3628

Grover, R.; Maguer, J-F.; Allemand, D. \& Ferrier-Pagès, C. (2008). Uptake of dissolved free amino acids by the scleractinian coral Stylophora pistillata. The Journal of Experimental Biology, Vol.211,pp. 860-865, ISSN: 0022-0949 
Hadfield, M.G. (2011). Biofilms and marine invertebrate larvae: what bacteria produce that larvae use as settlement sites. Annu. Rev. Mar. Sci., Vol.3, pp. 453-70, ISSN: 19411405

Harder , T.; Lau, S.C.K.; Dobretsov, S.; Fang, T.K. \& Qian, P-Y. (2003). A distinctive epibiotic bacterial community on the soft coral Dendronephthya sp. and antibacterial activity of coral tissue extracts suggest a chemical mechanism against bacterial epibiosis. FEMS Microbiology Ecology , Vol.43, pp. 337-347, ISSN: 0168-6496

Hall-Spencer, J.M.; Rodolfo-Metalpa, R.; Martin, S.; Ransome, E. Fine, M. et al. (2008). Volcanic carbon dioxide vents show ecosystem effects of ocean acidification. Nature, Vol 454, pp.96-99, ISSN: 0028-0836

Hay, M.E. (1997). The ecology and evolution of seaweed-herbivore interactions on coral reefs. Coral Reefs, Vol. 16, Suppl.: S67 - S76, ISSN: 0722-4028

Hill, M.; Hill, A.; Lopez, N. \& Harriott, O. (2006) Sponge-specific bacterial symbionts in the Caribbean sponge, Chondrilla nucula (Demospongiae, Chondrosida). Marine Biology, Vol.148, pp. 1221-1230, ISSN: 0025-3162

Hoffmann, F.; Larsen, O.; Thiel, V.; Rapp, H.T.; Pape, T.; Michaelis, W. \& Reitner, J. (2005). An anaerobic world in sponges. Geomicrobiology Journal, Vol.22, pp. 1-10, ISSN: 0149-0451

Hoffman, F.; Radax, R.; Woebken, D.; Holtappels, M.; Lavik, G. et al. (2009). Complex nitrogen cycle in the sponge Geodia barretti. Environ. Microbiol., Vol.11, No.9, pp. 2229-2243 ISSN: 14622912

Holmes, B. \& Blanch, H. (2007). Genus-specific associations of marine sponges with group I crenarchaeotes. Marine Biology, Vol.150: pp. 759-772, ISSN: 0025-3162

Hooper, J.N.A. \& Van Soest, R.W.M. (2002). Systema Porifera - a guide to the classification of sponges. Kluwer, Academic/Plenum Publishers, vol. 1, pp. 1-1101, vol. 2, pp. 1103-1708, ISBN: 0-306-47260-0

Houlbrèque, F. \& Ferrier-Pagès, C. (2009). Heterotrophy in tropical scleractinians corals. Biological Reviews, Vol.84, pp. 1-17, ISSN: 1464-7931

Hoyos, L.R. (2010). Bacterial-invertebrate symbioses: from asphalt cold seep to shallow waters. PhD. Dissertation. Max-Planck Institut für Marine Mikrobiologie in Bremen, 200 pages.

Huggett, M.J.; Williamson, J.E.; De Nys, R.; Kjelleberg, S. \& Steinberg, P.D. (2006). Larval settlement of the common Australian sea urchin Heliocidaris erythrogramma in response to bacteria from the surface of coralline algae. Oecologia , Vol.149, pp. 604619, ISSN: 0029-8549

Jackson, J.B.C. \& Buss, L. (1975). Allelopathy and spatial competition among coral reef invertebrates. PNAS, Vol.72, No12, pp. 5160-5163, ISSN: 0027-8424

Javaux, E.J.; Knoll, A.H. \& Walter, M.R. (2004). TEM evidence for eukaryotic diversity in mid-Proterozoic oceans. Geobiology, Vol.2, pp. 121-132, ISSN: 1472-4669

Johnson, C.R.; Muir, D.G. \& Reysenbach, A.L. (1991). Characteristic bacteria associated with surfaces of coralline algae: a hypothesis for bacterial induction of marine invertebrate larvae. Mar. Ecol. Prog. Ser., Vol.74, pp. 281-294, ISSN: 0171-8630

Johnson, C.R. \& Sutton, D.C. (1994). Bacteria on the surface of crustose coralline algae induce metamorphosis of the crown-of-thorns starfish Acanthaster planci. Marine Biology, Vol.120, pp. 305-310, ISSN: 0025-3162 
Joint, I.; Tait, K. \& Wheeler, G. (2007). Cross-kingdom signalling: exploitation of bacterial quorum sensing molecules by the green seaweed Ulva. Phil. Trans. R. Soc. B 2007, Vol.362, pp. 1223-1233, ISSN: 0962-8436

Kamke, J.; Taylor, M.W. \& Schmitt, S. (2010). Activity profiles for marine sponge-associated bacteria obtained by $16 \mathrm{~S}$ rRNA vs $16 \mathrm{~S}$ rRNA gene comparisons. The ISME Journal, Vol.4, pp. 498-508, ISSN: 1751-7362

Kang, S-H. \& Lee K-W. (2002). Phylogenetic relationships between Ulva conglobata and $U$. pertusa from Jeju Island inferred from nrDNA ITS 2 sequences. Algae, Vol.17, No2, pp. 75-81, ISSN: 1226-2617

Keeling, P. J. (2010). The endosymbiotic origin, diversification and fate of plastids. Phil. Trans. R. Soc. B, Vol. 365, pp. 729-748, ISSN: 0962-8436

Kim, D.E.; Lee, E.Y. \& Kim H.S. (2009). Cloning and Characterization of Alginate Lyase from a Marine Bacterium Streptomyces sp. ALG-5. Mar Biotechnol, Vol.11, pp. 10-16, ISSN: 1436-2228

King, N.; Westbrook, J; Young, S.L.; Kuo, A.; Abedin, M. et al. (2008). The genome of the choanoflagellate Monosiga brevicollis and the origin of metazoans. Nature, Vol.451, pp. 783-788, ISSN: 0028-0836

Kinzie, R.A. ; Takayama, M. ; Santos, S. \& Crofforth, M.A. (2001) The adaptive bleaching hypothesis: experimental test of critical assumptions. Biol. Bull. Vol.200, pp. 51-58, ISSN: 0006-3185

Kitamura, M.; Koyama, T.; Nakano, Y. \& Uemura, D. (2007). Characterization of a natural inducer of coral larval metamorphosis. J. Exp. Mar. Biol. Ecol.,Vol.340, No1, pp. 96102, ISSN: 0022-0981

Kladi, M.; Vagias, C. \& Roussis, V. (2004) Volatile halogenated metabolites from marine red algae. Phytochemistry Reviews 3, 337-366, ISSN: 1568-7767

Klein, J. \& Verlaque, M. (2008). The Caulerpa racemosa invasion: a critical review. Marine Pollution Bulletin, Vol.56, pp. 205-225, ISSN: 0025-326X

König, G.M.; Kehraus. S.; Seibert, S.F.; Abdel-Lateff, A. \& Müller, D. (2006) Natural Products from Marine Organisms and Their Associated Microbes. ChemBioChem., Vol.7, pp. 229 - 238, ISSN: 1439-4227

Kornprobst, J-M. (2010a). Algae. Vol.1, pp. 251-440. In: Encyclopedia of Marine natural Products. Wiley-Blackwell Verlag GmbH \& Co. KGaA, Weinheim, Germany, 1594 pp. (3 vols); ISBN; 978-3-527-32703-4

Kornprobst, J-M. (2010b). Porifera (sponges). Vol. 2. In: Encyclopedia of marine natural products. Wiley-Blackwell, Verlag GmbH \& Co. KGaA, Weinheim, Germany, 1594 pp. (3 vols); ISBN 978-3-527-32703-4

Kuntz, N.M.; Kline, D.I.; Sandin, S.A. \& Rohwer, F. (2005). Pathologies and mortality rates caused by organic carbon and nutrient stressors in three Caribbean coral species. Mar. Ecol. Prog. Ser., Vol.294, pp. 173-180, ISSN: 0171-8630

La Barre, S.C. \& Haras D. (2007). Rencontres avec les bactéries marines. J. Soc. Biol., Vol.201, No.3, pp. 281-289, ISSN: 1295-0661

La Barre, S.; Potin, P.; Leblanc, C. \& Delage, L. (2010).The halogenated metabolism of brown algae (Phaeophyta) - its biological importance and its environmental significance. Marine Drugs. 2010; 8(4), 988-1010, ISSN: 1660-3397

Lachnit T.; Wahl, M. \& Harder, T. (2010). Isolated thallus-associated compounds from the macroalga Fucus vesiculosus mediate bacterial surface colonization in the field 
similar to that on the natural alga. Biofouling, Vol.26, No.3, pp. 247-255, ISSN: 08927014

Lam, C. \& Harder, T. (2007). Marine macroalgae affect abundance and community richness of bacterioplancton in close proximity. J. Phycol., Vol. 43, pp. 874-881, ISSN: 00223646

Laming, K. (2010). Beneficial roles of microorganisms in the coral reef ecosystem. The Plymouth Student Scientist, Vol.3, No.2, pp. 289-299, ISSN: 1754-2383 (online)

Lang, J.C. \& Chornesky, E.A., 1990. Competition between scleractinian reef corals - a review of mechanisms and effects. In: Dubinsky, Z. (Ed.). Ecosystems of the World, Vol. 25. Elsevier, Amsterdam, pp. 209-252.

Largo, D.B.; Fukami, K. \& Nishijima, T. (1999). Time-dependent attachment mechanism of bacterial pathogen during ice-ice infection in Kappaphycus alvarezii (Gigartinales, Rhodophyta). Journal of Applied Phycology, Vol.11, pp. 129-136, ISSN: 0921-8971

Latham, H. (2008). Temperature stress-induced bleaching of the coralline alga Corallina officinalis: a role for the enzyme bromoperoxidase. Bioscience Horizons, Vol.1, No.2, pp. 104-113, ISSN: 1754-7431

Leggatt, W.; Ainsworth, T.; Bythell, J.; Dove, S.; Gates, R. et al. (2007). The hologenome theory disregards the coral holobiont. Nature Rev. Microbiol. Online correspondance, doi:10.1038/nrmicro1635C1, ISSN: 1740-1526

Li, Z. (2009). Advances in symbiotic cyanobacteria. In: Handbook on Cyanobacteria, eds. PM Gault \& HJ Marler, Nova Science Publishers Inc., chapter 16, pp. 1-10

Littman, R.A., Willis B. L., Pfeffer, C. \& Bourne, D. G. (2009). Diversities of coral-associated bacteria differ with location, but not species, for three acroporid corals on the Great Barrier Reef. FEMS Microbiol. Ecol., Vol. 68, pp. 152-153, ISSN: 0168-6496

Littman R.; Willis, B.L. \& Bourne, D.G. (2011). Metagenomic analysis of the coral holobiont during a natural bleaching event on the Great Barrier Reef Environmental Microbiology Reports ISSN: 1758-2229 (online), DOI: 10.1111/j.17582229.2010.00234.x

Lough, J.M. (2008). 10 ${ }^{\text {th }}$ anniversary review: a changing climate for coral reefs. Journal of Environmental Monitoring, Vol.10, No.1, pp 1-148, ISSN 1464-0325

Loughlane, C.J.; McIvor, L.M.; Rindi, F.; Stengel, D.B. \& Guiry, M. (2008). Morphology, rbcL phylogeny and distribution of distromatic Ulva (Ulvophyceae, Chlorophyta) in Ireland and southern Britain. Phycologia,Vol.47, No4, pp. 416-429, ISSN: 0031-8884

Maldonaldo, M. (2004). Choanoflagellates, choanocytes and animal multicellularity. Invertebrate Biology, Vol.123, No1, pp. 1-22, ISSN: 1077-8306

Manefield M.; Rasmussen T.B.; Henzter M.; Andersen J.B.; Steinberg P.; Kjelleberg S. \& Givskov M. (2002). Halogenated furanones inhibit quorum sensing through accelerated LuxR turnover. Microbiology, Vol.148, pp. 1119-1127, ISSN: 1350-0872

Manning, G.; Young, S.L.; Miller, W.T.; Zhai, Y. (2008). The protist, Monosiga brevicollis, has a tyrosine kinase signaling network more elaborate and diverse than found in any known metazoan. PNAS, Vol.105, No28, pp. 9674-9679, ISSN: 0027-8424

Maragos, J.E.; Crosby, M.P. \& McManus, J.W. (1996). Coral reefs and coral reef biodiversity: a critical and threatened relationship. Oceanography, Vol.9, No1, pp. 83-99, ISSN: $1042-8275$ 
Martone, P.T.; Alyono, M. \& Stites, S. (2010). Bleaching of an intertidal coralline alga: untangling the effects of light, temperature, and desiccation. Mar. Ecol. Prog. Ser., Vol.416, pp. 57-67, ISSN: 0171-8630

Marubini, F.; Ferrier-Pagès, C.; Furia, P. \& Allemand, D. (2008). Coral calcification responds to seawater acidification: a working hypothesis towards a physiological mechanism. Coral Reefs, Vol.27, pp.491-499, ISSN: 0722-4028

Matsuo, Y.; Imagawa, H.; Nishizawa, M. \& Shizuri, Y. (2005). Isolation of an algal morphogenesis inducer from a marine bacterium. Science, Vol.307, p. 1598, ISSN: 0036-8075

McConnell, O.J. \& Fenical, W. (1977) Halogen chemistry of the red alga Asparagopsis. Phytochemistry, Vol.16, pp. 367-369, ISSN: 0031-9422

Meron, D.; Atias, M.; Kruh, L.I.; Elifantz, H.; Mintz, D.; Fine, M. \& Banin, E. (2011). The impact of reduced $\mathrm{pH}$ on the microbial community of the coral Acropora eurystoma. The ISME Journal, Vol. 5, pp. 51-60,

Moberg, F. \& Folke, C. (1999). Ecological goods and services of coral reef ecosystems. Ecological Economics, Vol.29, pp. 215-233, ISSN 0921-8009

Mohamed, N.M.; Colman, A.S.; Tai, Y. \& Hill, R.T. (2008). Diversity and expression of nitrogen fixation genes in bacterial symbionts of marine sponges. Environ. Microbiol., Vol.10, No.11, 2910-2955, ISSN: 14622912

Mouchka, M.E.; Hewson, I. \& Harvell D. (2010). Coral-associated bacterial assemblages: current knowledge and the potential for climate-driven impacts. Integrative and Comparative Biology, Vol.50, No.4, pp. 662-674, ISSN: 1540-7063

Muscatine, L. \& Cerniciari, E. (1969). Assimilation of photosynthetic products of zooxanthellae by a reef coral. Biol. Bull. Vol.137, pp. 506-523, ISSN: 0006-3185

Mydlarz; L.D. \& Palmer, C.A. (2011). The presence of multiple phenoloxidases in Caribbean reef-building corals. Comparative Biochemistry and Physiology, Part A Vol. 159, pp. 372-378, ISSN: 1096-4959

Nedelcu, A.M.; Miles, I.H.; Fagir, A.M. \& Karol, K. (2008). Adaptive eukaryote-to-eukaryote lateral gene transfer: stress-related genes of algal origin in the closest unicellular relatives to animals. J. Evol. Biol., Vol.21, pp. 1852-1860, ISSN: 1420-9101

Negri, A.P.; Webster, N.S.; Hill, R.T. \& Heyward, A.J. (2001). Metamorphosis of broadcast spawning corals in response to bacteria isolated from crustose algae. Mar. Ecol. Prog. Ser.,Vol.223, pp. 121-131, ISSN: 0171-8630

Nishizawa, M.; Iyenaga, T.; Kurisaki, T.; Yamamoto H.; Sharfuddin M. et al. (2007). Total synthesis and morphogenesis-inducing activity of $( \pm)$-thallusin and its analogues. Tetrahedron Letters, Vol.48, pp. 4229-4233, ISSN: 0040-4039

Olson, J. \& Kellogg, C.A. (2010). Microbial ecologyof corals, sponges and algae in mesophotic coral environments. FEMS Microbiol. Ecol., Vol. 73, pp. 17-30, ISSN: 0168-6496

Palmer, C.A., Bythell, J.C. \& Willis, B.L. (2010). Levels of immunity parameters underpin bleaching and disease susceptibility of reef corals. The FASEB Journal, Vol. 24, pp. 1935 - 1946, ISSN: 0892-6638

Palmer, C.A., Bythell, J.C. \& Willis, B.L. (2011). A comparative study of phenoloxidase activity in diseased and bleached colonies of the coral Acropora millepora. Developmental and Comparative Immunology, Vol. 35, pp. 1096-1099, ISSN: 0145- 305X 
Pantos, O. \& Bythell, J.C. (2010). A novel reef coral symbiosis. Coral Reefs, Vol. 29, pp. 761770

Paul, V.J.; Ritson-Williams, R. \& Sharp, K. (2011). Marine chemical ecology in benthic environments. Nat. Prod. Rep., Vol.28, pp. 345-387, ISSN: 0265-0568

Quévrain, E.; Roué, M.; Domart-Coulon, I.; Ereskovski, A.; Perez, T. \& Bourguet-Kondracki, M-L. (2009) Novel natural parabens produced by a Microbulbifer bacterium in its calcareous sponge host Leuconia niveae. Environ. Microbiol., Vol.11, No6, pp. 15271539, ISSN: 14622912

Rao, D.; Webb, S. \& Kjelleberg, S. (2006). Microbial colonization and competition on the marine alga Ulva australis. Appl. And Environ. Microbiol., Vol.72, No8, pp. 5547-5555, ISSN: 0099-2240

Rasher, D.B. \& Hay, M.E. (2010a). Seaweed allelopathy degrades the resilience and function of coral reefs. Communicative \& Integrative Biology, Vol.3, No6, pp. 564-566, ISSN: 1942-0889

Rasher, D.B. \& Hay, M.E. (2010b). Chemically rich seaweeds poison corals when not controlled by herbivores. PNAS, Vol.107, No.21, pp. 9683-9688, ISSN: 0027-8424

Reiswig, H.M. (1971). Particle feeding in natural populations of three marine demosponges. Biol Bull., Vol.141, pp. 568-591, ISSN: 0006-3185

Reitzel, A.M.; Sullivan, J.C.; Traylor-Knowles N. \& Finnerty, J.R. (2008). Genomic survey of candidate stress-response genes in the estuarine anemone Nematostella vectensis. Biol. Bull. Vol.21 pp.: 233-254, ISSN: 0006-3185

Reyes-Bermudez, A. (2009). Cellular mechanisms of coral calcification. PhD thesis, James Cook University of North Queensland, 145pp with figures. (http:/ / eprints.jcu.edu.au/8084)

Rohwer, F. (2010). Coral reefs in the microbial seas. Plaid Press, USA, 201 pages, ISBN: 9780-9827012-0-1.

Rosenberg, E.; Koren, O.; Reshef, L.; Efrony, R. \& Zilber-Rosenberg, I. (2007)a. The role of microorganisms in coral health, disease and evolution. Nature Rev. Microbiol., Vol.5, pp. 355-362, ISSN: 1740-1526

Rosenberg E;, Koren O.; Reshef L; Efrony R. \& Zilber-Rosenberg, I. (2007)b. The hologenome theory disregards the coral holobiont: reply from Rosenberg et al. Nature Rev. Microbiol. Online correspondance. doi:10.1038/nrmicro1635C2, ISSN: 1740-1526

Roué, M.; Domart-Coulon, I.; Ereskovski, A.; Djediat, C.; Perez, T. \& Bourguet-Kondracki, M-L (2010). Cellular localization of clathridimine, an antimicrobial 2aminoimidazole alkaloid produced by the mediterranean calcareous sponge Clathrina clathrus. J. Nat. Prod., Vol.73, No.7, pp. 1277-1282, ISSN: 0163-3864

Salih, A.; Larkum, T.; Cox, G.; Kühl, M. \& Hoegh-Guldberg, O. (2000). Fluorescent pigments in corals are photoprotective. Nature, Vol.408, pp. 850-853, ISSN: 0028-0836

Sammarco, P.W.; Hallock, P.; Lang, J.C. \& LeGore, R.S. (2007). Roundtable discussion groups summary papers: environmental bio-indicators in coral reef ecosystems: the need to align research, monitoring, and environmental Regulation. Environmental Bioindicators, Vol.2, pp. 35-46, ISSN: 1555-5275

Sammarco, P.W. \& Strychar, K.B. (2009). Effects of climate change/global warming on coral reefs: adaptation/exaptation in corals, evolution in zooxanthellae, and biogeographic shifts. Environmental Bioindicators, Vol.4, pp. 9-45, ISSN: 1555-5275 
Santiago-Vasquez L.Z.; Ranzer, L.K. \& Kerr, R.G. (2006). Comparison of two total RNA extraction protocols using the marine gorgonian coral Pseudopterogorgia elisabethae and its symbiont Symbiodinium sp. Electronic Journal of Biotechnology, Vol.9, No.5, Issue of October 15, pp. 598-603, ISSN: 0717-3458

Schlappy, M-L.; Schöttner, S.I.; Lavik, G.; Kuypers, M.M.; de Beer, D. \& Hoffmann, F. (2010). Evidence of nitrification and denitrification in high and low microbial abundance sponges. Marine Biology, Vol.157, pp. 593-602, ISSN: 0025-3162

Schönberg, C.H.; Suwa, R.; Hidaka, M. \& Loh, W.K.W. (2008). Sponge and coral zooxanthellae in heat and light: preliminary results of photochemical efficiency monitored with pulse amplitude modulated fluorometry. Marine Ecology, Vol.29, pp. 247-258, ISSN: 0173-9565

Selvin, J.; Gandhimathi, R.; Kiran, G.S.; Priya, S.S.; Ravji, T.R. \& Hema, T.A. (2009). Culturable heterotrophic bacteria from the marine sponge Dendrilla nigra: isolation and phylogenetic diversity of actinobacteria. Helgol. Mar. Res., Vol. 63, pp. 239-247, ISSN: $1438-3888$

Siboni, N.; Ben-Dov, E.; Sivan, A. \& Kushmaro, A. (2008). Coral-associated ammonium oxidizing Crenarchaeota and their role in the coral holobiont nitrogen cycle. Proceedings of the 11th International Coral Reef Symposium, Ft. Lauderdale, Florida, 711 July 2008, pp. 252-256, doi:10.1111/j.1462-2920.2007.01383.x

Smyrniotopoulos, V.; Vagias, C.; Rahman, M.M.; Gibbons, S. \& Roussis V. (2010). Structure and antibacterial activity of brominated diterpenes from the red alga Sphaerococcus coronopifolius. Chemistry and Biodiversity, Vol. 7, pp. 186-195, ISSN: 1612-1872

Sogin, M; Morrison, H.G. ; Huber, J.A.; Welch, D.M.; Huse, S.M. et al. (2006). Microbial diversity in the deep sea and the underexplored "rare biosphere". PNAS, Vol. 103, No.32, pp. 12115-12120, ISSN: 0027-8424

Sotka, E.E. \& Hay, M.E. (2009). Effects of herbivores, nutrient enrichment, and their interactions on macroalgal proliferation and coral growth. Coral Reefs, Vol.28, pp. 555-568, ISSN: 0722-4028

Srivastava, M.; Simakov, O.; Chapman, J.; Fahey, B.; Gauthier, M.A. et al. (2010). The Amphimedon queenslandica genome and the evolution of animal complexity. Nature, Vol.466, pp. 720-727, ISSN: 0028-0836

Stanley, S.M. \& Hardie, L.A. (1998). Secular oscillations in the carbonate mineralogy of reefbuilding and sediment-producing organisms driven by tectonically forced shifts in seawater chemistry. Palaeogeography, Palaeoclimatology, Palaeoecology, Vol.144, pp. 319, ISSN: 0031-0182

Stat, M. \& Gates, R.D. (2011). Clade DSymbiodinium in Scleractinian Corals: A "Nugget" of Hope, a Selfish Opportunist, an Ominous Sign, or All of the Above? Journal of Marine Biology Vol. 2011, Article ID 730715, 9 pages, doi:10.1155/2011/730715

Steneck, R.S. \& Martone, P.T. (2007). "Calcified algae." In: Encyclopedia of Tidepools, eds. M.W. Denny \& S.D. Gaines. pp 21-24. University of California Press, ISBN: Berkeley. ISBN: 3-7653-9271-5

Stewart, P.; Soonklang, N.; Stewart, M.J.; Wanichanon, C.; Hanna PJ, et al.(2008). Larval settlement of the tropical abalone, Haliotis asinina Linnaeus, using natural and artificial chemical inducers. Aquaculture Research, Vol.39, No.11, pp. 1181-1189, ISSN: 1355-557X 
Suggett DJ \& Smith DJ (2011). Interpreting the sign of coral bleaching as friend vs. foe. Global Change Biology, Vol.17, pp. 45-55, ISSN: 1354-1013

Talmage, S.C. \& Glober, C.J. (2010). Effects of past, present, and future ocean carbon dioxide concentrations on the growth and survival of larval shellfish. PNAS, Vol.107, No40, pp. 17246-17251, ISSN: 0027-8424

Tanaka, Y.; Ogawa, H. \& Miyajima, T. (2010). Effects of nutrient enrichment on the release of dissolved organic carbon and nitrogen by the scleractinian coral Montipora digitata. Coral Reefs, Vol.29, pp. 675-682, ISSN: 0722-4028

Taris, N.; Comtet, T., Stolba, R.; Lasbleiz, R.; Pechenik, J.A. \& Viard F. (2010). Experimental induction of larval metamorphosis by a naturally-produced halogenated compound (dibromomethane) in the invasive mollusk Crepidula fornicata (L.). J. Exp. Mar. Biol. Ecol., Vol.293, pp. 71-77, ISSN: 0022-0981

Teo, S.E.; Ho, C.L.; Teoh, S. \& Rahim, R.A. (2009). Transcriptomic analysis of Gracillaria changii (Rhodophyta) in response to hyper- and hypo- osmotic stresses. Journal of Phycology, Vol.45, No5, pp. 1093-1099, ISSN: 0022-3646

Thacker, R.W. \& Starnes, S. (2003). Host specificity of the symbiotic cyanobacterium Oscillatoria spongeliae in marine sponges, Dysidea spp. Marine Biology, Vol.142, pp. 643-648, ISSN: 0025-3162

Thacker, R.W. (2005). Impacts of shading on sponge-cyanobacteria symbioses: a comparison between host-specific and generalist associations. Integrative and Comparative Biology, Vol.45, pp. 369-376, ISSN: 1540-7063

Thajuddin, N. \& Subramanian, G. (2005). Cyanobacterial biodiversity and potential applications in biotechnology. Current Science, Vol.89, No1, pp. 47-57, ISSN: 00113891

Thiel, V.; Leininger, S.; Schmaljohann, R.; Brümmer, F. \& Imhoff, J.S. (2007). Sponge-specific bacterial associations of the Mediterranean sponge Chondrilla nucula (Demospongiae, Tetractinomorpha). Microbial Ecology, Vol.54, pp. 101-111, ISSN: 0095-3628

Tujula, N.A.; Crocetti, G.R.; Burke, C.; Thomas, T.; Holmström, C. \& Kjelleberg; S. (2010). Variability and abundance of the epiphytic bacterial community associated with a green marine Ulvacean alga. The ISME Journal, Vol.4, pp. 301-311, ISSN: 1751-7362

Turque, A.S.; Batista, D.; Silveira, C.B.; Cardoso, A.M.; Viera, R.P. et al. (2010). Environmental shaping of sponge-associated archaeal communities. PLoS ONE, Vol.5, No12, e15774, pp. 1-10, ISSN: 1932-6203

Usher, K.M.; Kuo, J.; Fromont, J. \& Sutton, D. (2001) Vertical transmission of cyanobacterial symbionts in the marine sponge Chondrilla australiensis (Demospongiae). Hydrobiologia, Vol.461, pp. 15-23, ISSN: 0018-8158

Usher, K.M. (2008). The ecology and phylogeny of cyanobacterial symbionts in sponges. Marine Ecology, Vol.29, pp. 178-192, ISSN: 0173-9565

Vacelet, J. (1970) Description de cellules à bactéries intranucléaires chez des éponges Verongia. J. Microscopie, Vol.9, No.3, pp. 333-346, ISSN: 1365-2818

Vacelet, J.; Fiala-Medioni, A.; Fisher, C.R. \& Boury-Esnault, N. (1996). Symbiosis between methane-oxidizing bacteria and a deep-sea carnivorous cladorhizid sponge. Mar. Ecol. Prog. Ser., Vol.145, pp. 77-85., ISSN: 0171-8630 
Vairappan, C.S. (2006). Seasonal occurrences of epiphytic algae on the commercially cultivated red alga Kappaphycus alvarezii (Solieriaceae, Gigartinales, Rhodophyta). Journal of Applied Phycology, Vol.18, pp. 611-617, ISSN: 0921-8971

Vega Thurber, R.L.; Barott, K.L.; Hall D.; Liu, H.; Rodriguez-Mueller, B. et al. (2008). Metagenomic analysis indicates that stressors induce production of herpes-like viruses in the coral Porites compressa. PNAS, Vol.105, No.47, pp. 18413-18418, ISSN: 0027-8424

Vega Thurber, R.L.; Willner-Hall, D.; Rodriguez-Mueller, B.; Desnues, C.; Edwards, R.A. et al. (2009). Metagenomic analysis of stressed coral holobionts. Environmental Microbiology Vol.11, No.8, pp. 2148-2163, ISSN 1462-2920

Veron, J.E. (2008). Mass extinctions and ocean acidification: biological constraints on geological dilemmas. Coral Reefs, Vol.27, pp. 459-472, ISSN: 0722-4028

Vidal-Dupiol, J.; Adjeroud, M.; Roger, E.; Foure, L.; Duval, D. et al. (2009). Coral bleaching under thermal stress: putative involvement of host/symbiont recognition mechanisms. BMC Physiology, Vol.9, No.14, doi:10.1186/1472-6793-9-14

Wang, G.; Shuai L.; Li Y.; Lin W.; Zhao X. \& Duian D. (2008). Phylogenetic analysis of epiphytic marine bacteria on Hole-Rotten diseased sporophytes of Laminaria japonica. J. Appl. Phycol., Vol.20, pp. 403-409, ISSN: 0921-8971

Webster, N.; Webb, R.I.; Ridd, M.J.; Hill, R.T., Negri, A.P. (2001). The effects of copper on the microbial community of a coral reef sponge. Environ. Microbiol., Vol.3, No1, pp. 1931, ISSN: 14622912

Webster, N.A.; Smith, L.D.; Heyward, A.J.; Watts, J.E.M.; Webb, R.I. et al. (2004). Metamorphosis of a scleractinian coral in response to bacterial biofilm. Appl. Environ. Microbiol. Vol.70 No2, pp. 1213-1221, ISSN: 0099-2240

Webster NS and Hill RT (2007) Chapter 5 Vulnerability of marine microbes on the Great Barrier Reef to climate change. pp. 97-120. In: Johnson JE and Marshall PA (eds) Climate change and the Great Barrier Reef: A vulnerability assessment. Great Barrier Reef Marine Park Authority and the Australian Greenhouse Office, Department of the Environment and Water Resources. 818 p.

Webster, N.S.; Cobb, R.E. \& Negri, A.P. (2008). Temperature threshold for bacterial symbiosis with a sponge. The ISME Journal,Vol.2, pp. 830-842, ISSN: 1751-7362

Webster, N.S.; Soo, R.; Cobb, R. \& Negri, A.P. (2010)a. Elevated seawater temperature causes a microbial shift on crustose coralline algae with implications for the recruitment of coral larvae. The ISME Journal (2010), pp. 1-12, ISSN: 1751-7362

Webster, N.S.; Taylor, M.W.; Benham, F.; Lücker, S.; Rattei, T. et al. (2010b) Deep sequencing reveals exceptional diversity and modes of transmission for bacterial sponge symbionts. Environ. Microbiol., Vol.12, No8, pp. 2070-2082, ISSN: 1462-2912

Webster, N. (2011). Sponge symbionts: sentinels of marine ecosystem health. $1^{\text {st }}$ Int. Symp. on Sponge Microbiology, March 21-22, Würzburg, Germany.

Wegley, L.; Yu, Y.; Breitbart, M.; Casas, V.; Kline, D. \& Rohwer, F. (2004). Coral-associated archaea. Mar. Ecol. Prog. Ser., Vol.273, pp. 89-96, ISSN: 0171-8630

Wegley, L.; Edwards, R.; Rodriguez-Brito, B.; Liu, H. \& Rohwer, F. (2007). Metagenomic analysis of the microbial community associated with the coral Porites astreoides. Environmental Microbiology (Vol.9, No11 pp. 2707-2719, ISSN: 1462-2912

Weinberger, F. (2007). Pathogen-induced defense and innate immunity in macroalgae. Biol. Bull., Vol.213, pp. 290-302, ISSN 1062-3590 
Weiner, S. \& Dove, P. (2003). An overview of biomineralization processes and the problem of vital effect. In: Biomineralization. Reviews in Mineralogy \& Geochemistry. Eds. Dove, P.M., DeYoreo, J.J. and Weiner, S. Vol. 54, pp. 1-29

Weisz, J.B.; Massaro, A.J.; Ramsby, B.D. \& Hill, M. (2010). Zooxanthellar symbionts shape host sponge trophic status through translocation of carbon. Biol. Bull., Vol.219, pp. 189-197, ISSN: 0006-3185

Weisz, J.H.; Lindquist, N. \& Martens, C.S. (2008). Do associated microbial abundances impact marine demosponge pumping rates and tissue densities? Oecologia, Vol.155, pp. 367-376, ISSN: 0029-8549

Welsh, D.T.; Viaroli, P.; Hamilton, W.D. \& Lenton, T.M. (1999). Is DMSP synthesis in chlorophycean macro-algae linked to aerial dispersal? Ethology Ecology E Evolution, Vol.11, pp. 265-278, ISSN: 0394-9370

Wild, C.; Huettel, M.; Klueter,A.; Kremb, S.; Rasheed, M.Y.M. \& Jorgensen B.B. (2004). Coral mucus functions as an energy carrier and particle trap in the reef ecosystem. Nature, Vol.428, pp. 66-70, ISNN: 0028-0836

Wild C., Rasheed M., Jantzen C., Cook P., Struck U., Huettel M. \& Boetius A. (2005). Benthic metabolism and degradation of natural particulate organic matter in carbonate and silicate reef sands of the northern Red Sea. Mar. Ecol. Prog. Ser., Vol. 298, pp. 69-78, ISSN: 0171-8630

Wild, C.; Hoegh-Guldberg, O.; Naumann, M.S.; Colombo-Pallotta, F.; Ateweberhan, M. et al. (2011). Climate changes impede scleractinian corals as primary reef ecosystem engineers. Marine and Freshwater Research, Vol.62, pp. 205-215, ISSN: 1323-1650

Williams, E.A.; Craigie, A; Yates, A. \& Degnan, S.M. (2008). Articulated coralline algae of the genus Amphiroa are highly effective natural inducers of settlement in the tropical abalone Haliotis asinine. Biol. Bull., Vol.215, pp. 98-107, ISSN: 0006-3185

Wong, K.K.W.; Lane, A.C.; Leung, P.T.W. \& Thiyagarajan, V. (2011, in press). Response of larval barnacle proteome to CO2-driven seawater acidification. Comp. Biochem. Physiol. Part D, 12 pages, in press.

Woods Hole Oceanographic Institute: http://www.whoi.edu/OCB-OA/FAQs/)

Woolard, F.X.; Moore, R.E. \& Roller, P.P. (1979). Halogenated acetic and acrylic acids from the red alga Asparagopsis taxiformis Phytochemistry 18 (4), Vol.18, No4, pp. 617-620, ISSN: 0031-9422 